\title{
Analysis of Households' Willingness to Pay for Improved Solid Waste Management Services in Gondar city, Ethiopia: Evidence from a double- bounded Dichotomous Contingent Valuation Method
}

Kassahun Tassie Wegedie ( $\square$ tasiekassahun@gmail.com )

Bahir Dar University College of Agriculture and Environmental Sciences https://orcid.org/0000-00033820-3332

\section{Anteneh Mulugeta Eyasu}

Bahir Dar University College of Agriculture and Environmental Sciences

Yenesew Sewnet Yizengaw

Bahir Dar University College of Agriculture and Environmental Sciences

Getnet Asifaw Shiferaw

University of Gondar Faculty of Agriculture

\section{Research}

Keywords: Better solid waste management service, WTP, CVM, Bivarite probit model, Gondar City

Posted Date: December 3rd, 2020

DOl: https://doi.org/10.21203/rs.3.rs-117252/v1

License: (c) (1) This work is licensed under a Creative Commons Attribution 4.0 International License. Read Full License 


\title{
Analysis of households' willingness to pay for improved solid waste management Services in Gondar city, Ethiopia: evidence from a double-bounded dichotomous contingent Valuation Method
}

\author{
Kassahun Tassie ${ }^{1 a^{*} ;}$ Anteneh Mulugeta ${ }^{1 b}$, Yenesew Sewunet ${ }^{1 \mathrm{c}}$, Getnet Assfaw $^{2}$; \\ 1a*Bahir Dar University, College of Agriculture and Environmental Science, Department of Agricultural Economics \\ Email: tasiekassahun@gmail.com
}

\section{Abstract}

Background: Waste is a byproduct of human life. Nowadays, municipal solid waste is being produced in excessive amounts and in this way, both developing and developed countries are facing challenges regarding generation of waste. Economic development, urbanization and improved living standards in cities have contributed to increase in the amount and complexity of solid waste produced.

Methods: this study aims to Analysis of households' willingness to pay for improved solid waste management Services in Gondar city, Ethiopia: evidence from a double-bounded dichotomous contingent Valuation Method.

Result: A total of 222 randomly selected households were interviewed to address the objective of this study. Finally, the survey result indicated that 192(87.3\%) of sample households were willing to pay for improved solid waste management services. Following this, the one and double-bounded dichotomous contingent valuation result revealed that the mean willingness to pay estimated from the Double Bounded dichotomous CVM and open ended formats were 34.48 and $17.0756 \mathrm{ETB}^{1}$ per month per households respectively. The total WTP was obtained by adding the WTP of the total households in each stratum, and is equal to 941361ETB and 1900848 ETB for open ended and double bounded format, respectively. Additionally, the bivariate probit model result demonstrated that income and education have positive and significant effects on willingness to pay bid amounts. The results, age, marital status, Bidl and Bid2 have a negative and significant effect on households' amount of willingness to pay for better solid waste management services.

Conclusion: When allocating service charges the city municipality considers amount of solid waste generation and income level of the households. The study results show that when educational status of the households increases and increase their willing to participate in planned improved solid waste management service. Thus, awareness creation is importance for better solid waste management. Additionally the city municipality facilitates a learning media for uneducated households to come up with at least secondary education level.

Keywords: Better solid waste management service, WTP, CVM, Bivarite probit model, Gondar City

\footnotetext{
${ }^{1}$ The official exchange rate of $1 \$=29.45$ Ethiopian Birr (ETB)
} 


\section{Introduction}

Nowadays, in the $20^{\text {th }}$ century the world's environment gets polluted and its comfortability for life becoming decline. Among those environmental issues solid waste management /SWM/ is a critical one because humans have been living in settled communities [1,2]. Solid waste is continually growing problem at global and one of the most intractable problem for local authorities in urban centers [3]. Greater economic prosperity and increase in the consumption level have intensified the problem of SWM and is now a major challenge in urban areas of developing countries [4, 5]. In 2012, the world's cities generated 1.3 billion tons of solid waste per year and, amounting to a rate of $1.2 \mathrm{~kg}$ per person per day. With rapid population growth and urbanization, municipal waste generation is expected to rise to 2.2 billion tons by 2025 and about $85.8 \%$ waste generated by households [6, 7]. In sub-Saharan Africa, waste generation is approximately 62 million tons per year ranging from 0.09 to $3.0 \mathrm{~kg}$ per person per day, with an average of $0.65 \mathrm{~kg} / \mathrm{capita} /$ day $[8,9]$.

In Africa, municipal SWM constitutes one of the most crucial health and environmental problems facing governments of African cities including Ethiopia [10, 11]. In Africa, SWM is anticipated that the worst (in terms of increasing waste generation and poor management practice) is yet to be experienced in the view of rapid development process, lack of proper planning and management of equipment for solid waste disposal in the continent $[12,13]$. By 2030, Africa is expected to have an urban population of over $50 \%$, with urban growth rate of $3.4 \%$ [14-16]. The fear has been heighted by the changing dynamics of waste composition and generating an ever-increasing volume of waste due to globalization and the peoples changing consumption pattern [17]. The increasing presence of non-biodegradable and hazardous waste types means that safe collection, transportation and disposal are absolutely crucial for public health sustainability. Since, indiscriminate and improper dumping of Municipal Solid Waste (MSW), in particular, widespread dumping of waste in water bodies and uncontrolled dump sites, aggravates the problems of generally low sanitation levels across the African continent [18].

Admittedly, SWM is a herculean tasks are not exclusive to the local and national government of Ethiopia as well. The per capita amount of solid waste generated in Ethiopia ranges from 0.28 to $0.83 \mathrm{~kg} /$ person/ day as opposed to $0.7 \mathrm{~kg}-1.2 \mathrm{~kg} /$ person/day in developed countries [17, 19], and it lacks the financial resources to improve sanitary facilities and institutional capacity to provide the needed municipal infrastructure for adequate SWM [20]. In Ethiopia, the government realized that it is impossible to address the problem of environment, particularly SWM, without involvement of local communities for sustainability of funds to manage SWM services. The most significant aspect of municipal SWM is collection and transportation of solid waste as it demands the major share of municipal 
budget and has the greatest impact on urban life and also places a heavy burden on the economy of the country $[21,22]$. To minimize these problems the participation of local communities or service receivers is important in providing solutions to problems of SWM [23, 24].

Being one of the largest cities in Ethiopia, Gondar city is one of the highly expanding and rapidly growing urban centers in Ethiopia. With the current annual population growth rate of $6 \%$, the city population will double within 14 years and it has a great parallel result on solid waste generation and composition change $[25,26]$. Increase the population growth from time to time with quantity of economic activities in the cities urbanized and urbanizing areas generate a proportional amount of waste products [27-29]. However, SWM in Gondar is far from adequately organized, and is collected in traditional ways, in which people providing the service in the city use their family members [30]. Ninety-five percent of the collected amount of solid waste in Gondar city is indiscriminately thrown away at dumping sites on the periphery of the city, and sometimes dumped illegally at empty lots scattered throughout the city because cities and municipalities cannot cope with the accelerated pace of waste production [31]. There is no provision of bins and waste collection service charges, which are collected directly door-to-door by the waste operators, are not uniform, varying from 2 to $15 \mathrm{ETB}$ (US $\$ 0.10$ to $0.85 \mathrm{ETB}^{2}$ ) per household per week, depending on the size of the sack used to dispose the waste [31, 32]. Therefore, financial constraint proves to be the greatest hindrance for providing adequate SWM services in Gondar city.

Households which are the primary producers of solid waste and suffer from the effects of uncollected solid waste should be able to participate in improving SWM. The Ethiopian government had proclaimed the solid waste management proclamation in 2007 and encouraged community participation [33]. Despite this, waste management continue to be one of the major challenges that many urban centers of the country including Gondar city and also to improve SWM in cities in Ethiopia have focused on the technical supply aspects of the service, mostly ignoring the demand side of the SWM services, including the ability to pay the service charge in order for the service to be provided in a financially viable way, based on full cost recovery. However, there is limited evidence on the willingness to pay /WTP/ for improved solid waste management (ISWM) and associated factors in the study area. Therefore, this study of the existing condition of municipal SWM service and the determinant factors that affect household's WTP participation and amounts of offered price for the provision of SWM service in Gondar city, Ethiopia.

\section{Literature Review}

\footnotetext{
${ }^{2}$ The Birr is Ethiopia's national currency. At the time of this study, 1 Birr was equal to approximately US\$0.034.
} 


\subsection{Utility function for Solid waste management}

In order to find out the major factors that determines public WTP for improved SWM an economic model was developed following [33, 34]. In economics, we recognize that individuals have inclinations beyond goods from both market and non-market places. Consumer wants to capitalize their utility from quantity and quality of goods and services under their given budget restriction. Thus, the utility function can be framed as:

$$
U(w, g)-------------------------------------------1
$$

Where: $\mathrm{w}=\mathrm{SWM}$; $\mathrm{g}=$ composite of all market goods/services

Whereas the expenditure function is:

$e(p, w, u)------------------------------------------2$

Where: $\mathrm{p}=$ price and $\mathrm{u}=$ utility

Equations (2) the expenditure function dealings the lowest sum of cash the buyer essentially spend to attain the agreed level of utility. This is cumulative function of ' $p$ ' and ' $u$ ' and diminishing function of 'w'. Subsequently, customer wants to stay with the identical utility, it is suitable to practice spending minimization issue [35].

$$
\begin{aligned}
& \operatorname{Min}(g+p g)---------------------------------------3 \\
& \text { s.t } U=U(w, g)
\end{aligned}
$$

Where price of composite goods are equal to one ( $\mathrm{pg}=1)$.

The exceeding minimization problem can be resolved by adopting Lagrange's multiplier to obtain Hicksian demand for the analogous goods. The Hicksian demand is assumed by:

$h_{i}=h_{i}\left(p_{w}, u^{*}\right)------------------------------------------4$

Substituting the values of matching Hicksian demand in the lowest expenditure function we can calculate the least expenditure function:

$e^{*}=e\left(p, w, u^{*}\right)-----------------------------------------5$

Where "e" is minimum expenditure required to achieve fixed level of utility " $u$ " and using the waste management "w", and the function of price of other goods, the fixed level of utility and the quality of SWM services itself.

The derivative of expenditure function with respect to price gives corresponding Hicks compensated demand function for good under consideration. 
$\partial e / \partial p_{i}=h_{i}\left(p_{w}, u^{*}\right)---------------------------------------6$ WTP for the change in SWM services is the integration of marginal WTP to achieve better waste management from " $\mathrm{w}$ " to " $\mathrm{W} *$ "

$W T P=-\int_{w}^{w^{*}} \partial e\left(w, u^{*}\right) / \partial w \cdot d w----------------------------------7$

WTP is the full amount of money a buyer would contribute to appreciate an enhancement in the value of life due to better SWM. The WTP for the improved SWM is:

$W T P=e(p, w, u)-e\left(p, w^{*}, u\right)----------------------------------8$

Where: "w" is a tainted level of waste management and " $\mathrm{w}$ *" is a better level of SWM.

The change is spending is either rewarding excess or corresponding surplus, if the situation is close of the initial utility, it is reimbursing and if the situation level of utility is final then it is corresponding surplus, Now taking into account the model findings, we can predict that HH's WTP, including other factors. Hence, to capture major determinants of WTP following regression model can be finalized and would be used for estimation.

$W T P_{i}=\alpha_{0}+\alpha_{1}\left(H_{i}\right)+\alpha_{2}\left(D_{i}\right)+\alpha_{3}\left(A_{i}\right)+\alpha_{4}\left(V_{i}\right)+u_{i}----------------------9$

Where: $W T P i=\mathrm{HH}$ 's willingness for better $\mathrm{SWM}$; $\mathrm{Hi}=$ Households features (education level, income, Family size, number of children, etc.), Di= Demographic characteristics' (age, sex, marital status, etc.), $\mathrm{A}=$ Responsibility of solid waste management, $\mathrm{V}_{\mathrm{i}}=$ cases of disease in the household.

\subsection{Empirical Studies}

Different articles were reviewed in relation to the WTP of respondents regarding to environmental resources. So, the results of the reviewed articles are summarized and presented both in narration and tabular form. The study conducted by Han, Yang [36] estimated WTP for environment conservation using CVM. The result indicated that $73 \%$ of the respondents were WTP for the conservation of the forest with average WTP of $\$ 8.03$ but $27 \%$ of the respondents were not WTP anything at all.

A study by Kalbali, Borazjani [37] analyzed factors affecting the WTP of visitors and the amount they are WTP for forest park using CV and application of Tobit model and estimated the average WTP of them for using the park. The report revealed that average WTP per visitor for each visit was estimated 2623 Rials and annual recreational value of the forest park was around 4 billion Rials. Additionally, Cho, Newman [38] measured rural homeowners' WTP for land conservation easements using CVM. The estimated result reported that household's WTP to participate in an easement program ranges from \$10.97 to \$21.79 per year per household. 
Estimated households' willingness to pay (WTP) for improved MSWM services in Kampala, Uganda [39]. A dichotomous choice contingent valuation technique was used to elicit households' WTP. The logit regression model was used to obtain the WTP of the households with sample size of 4015 households by applied systematic sampling method. Greater than $48 \%$ of households in Kampala were willing to pay for improved MSWM services with a mean monthly WTP of UGX 5,382 (USD 2.91). Also, a study on determinants of households WTP for solid waste collection services in Oyo state, Nigeria [40]with dichotomous choice CV technique was used to elicit households WTP. Total of 140 sample households were selected by systematic random sampling method and data collected with structured questionnaire. The data were analyzed using logit regression technique and results showed that the mean WTP of households for improved SWM is N 1240.92.

The study originated from Economic Valuation of Private Sector Waste Management Services with a contingent valuation survey in Ilorin stat, south west Nigeria [41]. The study was conducted in 224 sample households randomly after stratified the study area. A censored Tobit model was used to analysis results. The results show that more than $80 \%$ of the respondents were support of the residential waste management services. The respondents were WTP an average of 3,660 Nigerian Naira (US \$24) per year. Income, education, dwelling type and whether the respondent is satisfied with private sector participation in provision of SWM service were positively influenced the respondents' WTP.

A study on WTP for SWM Services in Islamabada, Pakistan Anjum [42], and stratified random sampling technique was applied for sample size selection of 500 respondents. A double bounded dichotomous choice questions followed by an open ended question format was used. The logistic regression estimation reveals that 65.4 percent of the total respondents are WTP, while the multiple regressions reveals a monthly mean WTP of Rs 289.15 which is greatly affected by household income, education and environmental awareness variables were positive and significant relationship with WTP, and household size was a negative and significant relationship with households WTP at 5\% significance level for all these variables. But age, service availability, and marital status of the respondent were not significant.

Study examined factors that might influence WTP for waste disposal among male and female gender in Ekiti State, Nigeria [43]. A total of 300 respondents were interviewed. The data collected was analyzed using descriptive analysis and probit regression. Results showed that $85.5 \%$ of the respondents were WTP for improved SWM while $14.5 \%$ were not willing. Probit regression analysis showed WTP for waste disposal was significantly affected by gender; nature of primary occupation, marital status, level of education and average monthly income. However, family size, household headship (significant and 
negative at $10 \%$ and $5 \%$ confidence level respectively), and nearness to dump site all have a negative relationship with WTP.

An analysis of households' WTP for better SWM services in urban areas of district Peshawar, Pakistan [44]. this study the CVM was used to analyze the determinants of households' WTP for improved water services by applying the open ended value elicitation format. The study used crosssectional data collected from 216 households selected through systematic random sampling method. From logit regression important results were obtained indicating that $49 \%$ of the samples HHs were willing to pay for better SWM services. The results further show $\mathrm{HH}$ size, Income of $\mathrm{HH}$ and higher education as important determinants of HH's WTP for better SWM services at 10\%, 5\% and 1\% significance levels respectively.

A study used CVM to determine the WTP of the poor for improved access to SW collection and disposal services, in the city of Kuala Lumpur, Malaysia [45]. Stratified quota random sampling methods were used along with the key stratification variable characteristics of household. Total sample size of 300 households and multiple linear regressions for data analysis were applied. The mean WTP from their study was MYR 13.00. The most significant factors in their study that affect WTP were respondents satisfaction with present waste collection services, income of respondents, gender, length of stay of residents in the area, and number of children's less than 12 ages. Finally a study of municipal solid waste management of Tinsukia Municipality of Assam in India [46]. They found that if the family income increases then the probability that the people are in favor of cost sharing is $13 \%$. The study further revealed that the amount of monthly waste generated per household has also influence on peoples WTP for SWM.

\section{Methods}

\subsection{Description of the study area}

Gondar city is one of the ancient and historical cities in Ethiopia which was emerged by emperor Fasiledess in 1636 and now it is the capital city of central Gondar zone (Figure 1). Gondar city located is $738 \mathrm{~km}$ far from Addis Ababa (capital city of Ethiopia) and $182 \mathrm{~km}$ from Bahir Dar city (capital city of Amhara National Regional State). It is located at 12030' North and 37020' East, and altitude of 1966 meter above sea level. The study area experiences average annual rainfall that ranges from 1200 $1600 \mathrm{~mm}$ and it has mean annual temperature of $26^{\circ} \mathrm{C}$ [30]. 


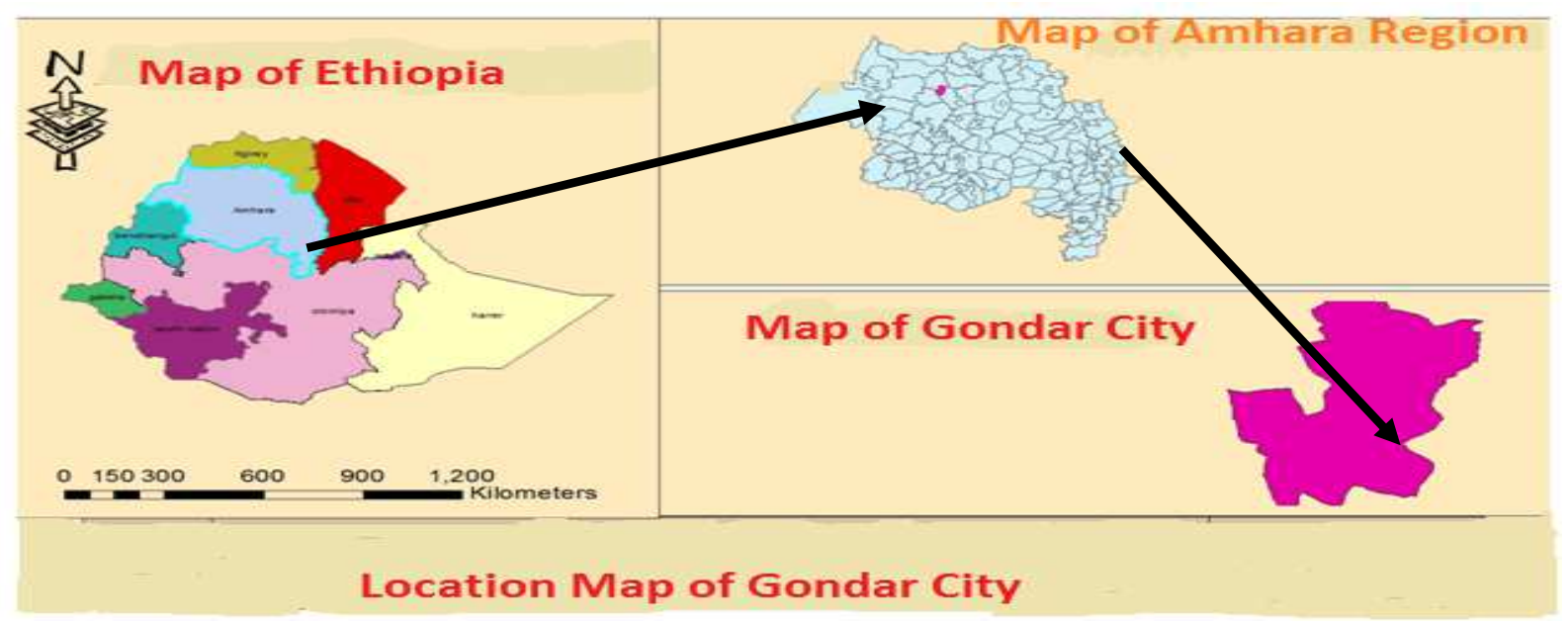

Figure 1: Location of the study area

It is a rapidly expanding town with commercial centers, small industries, and residences in all sectors of the town. Economically, Gondar city is among the surplus producing area of the country with a high potential for sesame farming and market. The city is also one of the major centers of tourism in Ethiopia since it is the home of Fasiledess castle and many historical churches. Gondar city has a total population 315856 which $47 \%$ are male and the remaining 53\% are females. In religious, $84.2 \%$ Orthodox Christian, $11.8 \%$ Muslims and $1.1 \%$ are others. The population density of the city increase time to time since rural residence migrates to urban (Annual report of GCAO, 2015).

\subsection{Sample Size and Sampling Technique}

Three professional enumerators were hired to gather households' WTP for better SWM service and its attributes by employing multistage sampling techniques. In, the first stage of sampling procedure was classifying 21 Kebelles into 3 strata (high waste generation, medium waste generation and low waste generation Kebelles) based on amount of household solid waste generated [47]. In the second stage, one sample Kebele was selected from each stratum by using simple random sampling method (lottery method) that represents the strata (totally 3 sample Kebelles were selected). On the third stage of sampling, from list of sampling frame representative sample households were selected randomly and the respondents from each selected sample Kebelles were identify by using proportionality. The survey, administered to heads of households or house wives because of the fact that he or she is in charge of a family and pays utility bills[48]. Moreover, face-to-face interview was chosen as a technique for eliciting data. According to Jianjun, Wenyu [49], face-to-face interview is the preferred technique to telephonic interviews oremail, because it provides the greatest scope for detailed questions and answers. Description of the sample size from each Kebele is summarized as Table 1below. 
The sample size was decided by using scientific statistical method developed by [50]. The formula that we used for determining sample size is the following:

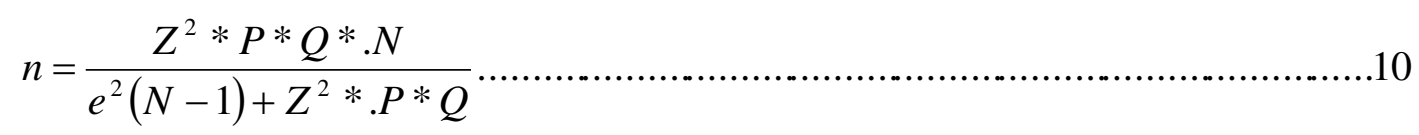

Where: $\mathrm{n}=$ the total desired minimum sample size; $\mathrm{N}=$ Total population in the sample three Kebelles (02, 11 and 16) (11483) based on [51]; $Z=$ standardized normal deviation at the required confidence level that corresponds to $95 \%$ confidence interval equal to 1.96 ; "P" is sample proportion of households of Gondar city that actually pay for solid waste management service that local government decide payment bids ( $82 \%$ ) and $\mathrm{Q}=1-\mathrm{P}$ (households actually not pay for solid waste management service that the government decide payment bids) (18\%) [30].

$$
\text { Thus, } n=\frac{1.96^{2} \times 0.18 \times 0.82 \times 11483}{(0.05)^{2}(11483-1)+1.96^{2} \times 0.18 \times 0.82}=222
$$

Representative and reasonable number samples for the study is 222 sample units.

Table 1: Sample size determination from sample Kebelles and Proportional Sample Size

\begin{tabular}{|l|l|c|c|c|}
\hline \multicolumn{1}{|c|}{$\begin{array}{c}\text { Group of } \\
\text { Kebelles }\end{array}$} & \multicolumn{1}{|c|}{ Kebelles } & $\begin{array}{c}\text { Sampled } \\
\text { Kebele }\end{array}$ & $\begin{array}{c}\text { Total No. of households } \\
\text { in the sample Kebele }\end{array}$ & Sample size \\
\hline $\begin{array}{l}\text { Low waste } \\
\text { generation }\end{array}$ & $\begin{array}{l}02,13,08,17,15 \text { and } \\
21\end{array}$ & 02 & 1790 & 35 \\
\hline $\begin{array}{l}\text { Medium waste } \\
\text { generation }\end{array}$ & $\begin{array}{l}01.03,04,05,06,07,09, \\
11,12 \text { and } 14\end{array}$ & 11 & 3423 & 66 \\
\hline $\begin{array}{l}\text { High waste } \\
\text { generation }\end{array}$ & $10,16,18,19,20$ & 16 & 6270 & 222 \\
\hline \begin{tabular}{l} 
Total \\
\hline
\end{tabular} & 21 & 3 Kebelles & 11483 & 222 \\
\hline
\end{tabular}

Source: Report [52]

\subsection{Survey structure}

In designing a contingent valuation survey, the proposed scenario should explain about the characteristics of the goods and services to be valued in order to be more clear and understandable, and enhance the credibility of the survey and produce reliable [53]. The questionnaire format consists of (i) introductory questions on SWM service provision; (ii) WTP questions on the SWM service connection; and (iii) questionnaires seeking respondents' information including different socio economic and demographic characteristics. The second part includes hypothetical scenario part that de-scribes the good, which is being valued, as described as below: 
For the CV, the welfare measure used was Compensating Surplus (Equation 1), i.e., WTP to obtain an improvement of SWM plan relative to the current plan. The affected attributes that were to be improved $\left(\mathrm{z}_{1}\right)$ followed that of the $\mathrm{CV}$, i.e;

a change of collection frequency from once times weekly and irregular (baseline) to 1 times every alternate days or 2 times weekly;

$\rightarrow$ a change in disposal method from open landfill (baseline) to control landfill;

$\rightarrow$ a change in the use of transportation from a mix of conventional open trucks and compactor (baseline) to only covered trucks and compactor; and

$\rightarrow$ the provision of free facilities and multiple containers for every household to facilitate mandatory recycling or waste separation at source - this ruling is assumed to be enforceable;

The SWM scenarios in CV were designed to be the similar so that meaningful comparisons can be made. It is an important objective of this study to understand how household WTP will change should recycling and waste separation at source was made mandatory. However, as payment for waste charges will not be made on a "pay per bag" or any unit-based pricing scheme, respondents are expected to display strategic behavior to support any recycling facilities but may not actually recycle their wastes in practice or demand lower waste charges. In order to capture the variation of WTP estimates, we administered 2 sets of $\mathrm{CV}$ questionnaire on separate samples. Version A considers all improvements in the attributes while version $\mathrm{B}$ considers all improvements except that recycling will not be made mandatory and there will be no provisions of facilities or containers for recycling or waste separation.

Before the $\mathrm{CV}$ questions were presented to respondents, there was a description of the current management plan in terms of the selected attributes and its implication on the environment and how they were paying for the waste services thus far. The improved management plan was then presented. Respondents were told explicitly that if they decided to vote for the improved plan, they would need to pay the monthly waste charges directly to the service provider, just the way they do for other utilities such as telephone lines and electricity. Respondents who voted for the improved plan were further asked to reveal their maximum monthly WTP (open ended format) to obtain the improvement. Since they did not know the amount of waste charges that they were actually paying currently, the respondents would need to reveal their true WTP, somewhat free of any anchoring bias. On the other hand, respondents who opted for the current management plan will not be asked any WTP question. Implicitly, they were assumed to be contented with the status quo and are willing to continue paying the unknown level of waste charges annually via the annual property assessment. In essence this CV approach was simply the traditional open- ended CV format but with some innovation in presenting the environmental market to help the 
respondents understand the proposed improved services better and quicker. See Table 2 for the CV questionnaire used in the study.

\section{Table 2: The CV Questionnaire}

Suppose the new management plan (Option 2) below is the only possible alternative to the current waste management practice (Option 1). Do you prefer to choose Option 1(collection frequency - 1 times weekly but irregular, no separation of waste at source needed, etc.), or Option 2 (collection frequency - 1 times weekly every alternate days, separation at source needed but containers are provided free of charge, etc. ).

[Enumerator needs forewarn the respondent that the payment will be made directly to the service provider and it is to replace any waste fee that is implicit in the house annual assessment charge]

\begin{tabular}{|l|}
\hline \multicolumn{1}{|c|}{ Implications } \\
\hline Collection frequency \\
\hline Separation of wastes at source \\
\hline Types of landfill \\
\hline Mode of Transportation \\
\hline Monthly charge \\
\hline
\end{tabular}

\begin{tabular}{|l|}
\hline \multicolumn{1}{|c|}{$\begin{array}{c}\text { Option 1 (current SWM } \\
\text { Option) }\end{array}$} \\
\hline $\begin{array}{l}\text { Once times weekly, irregular } \\
\text { days }\end{array}$ \\
\hline $\begin{array}{l}\text { Separation at source not } \\
\text { needed }\end{array}$ \\
\hline Open landfill \\
\hline $\begin{array}{l}\text { Compactor and conventional } \\
\text { open trucks }\end{array}$ \\
\hline $\begin{array}{l}\text { Unknown (indirect payment } \\
\text { via annual property } \\
\text { assessment) }\end{array}$ \\
\hline
\end{tabular}

\begin{tabular}{|l|}
\hline \multicolumn{1}{|c|}{ Option 2} \\
\hline $\begin{array}{l}\text { once times weekly (alternate } \\
\text { days) }\end{array}$ \\
\hline $\begin{array}{l}\text { Required but multiple free } \\
\text { containers provided }\end{array}$ \\
\hline Covered landfill /Control tipping \\
\hline Compactor and covered trucks \\
\hline $\begin{array}{l}\text { Need to pay monthly charge } \\
\text { directly to service providers }\end{array}$ \\
\hline
\end{tabular}

If the above two management options were the only ones possible, which one would you prefer? Simply tick the box under the Option that you prefer.

If you chose Option 2, what is your maximum monthly WTP to obtain the improvement? ETB_

\subsection{Elicitation method}

The study uses double bounded dichotomous choice (DBDC) elicitation formats, which are in accordance with [54-56]. This elicitation format presents every respondent with a sequence of two bids and asks the question twice which the second question entirely depends on the first question responses. That is based on respondents' initial response, they are asked new bids, higher if initial responses were 
'Yes', lower if their responses were 'No'. This method increases efficiency compared to single dichotomous choice model in such a way that the response sequences no-yes or yes-no improves bounds on WTP, the Yes-Yes and the No-No pairs also improve efficiency gain, and the number of responses increased which helps in fitting a given function due to more observations [57]. Hence, the DBDC formats of the study are summarized as below figure 2 .

Those who answered No-No in the survey are required to provide their reasons for not WTP and the reasons are recorded in an open-ended format. The follow up questionnaire helps in identifying the protest respondents who were excluded in our estimation of the WTP model in the later section.

The third section is designed to elicit the necessary socio-economic and demographic characteristics of the selected household units (education, age, type of work, marital status, family size, income, sex of household head and the others). The common problem in the CVM is the hypothetical bias ${ }^{3}$, where the hypothetical WTP for the SWM service overestimates the real WTP. Hence, in order to minimize the bias, the hypothetical scenario was developed being assisted by city municipality experts and local and professional enumerators were hired and trained with the context of this research questionnaires in order to smoothly approach the respondents and conduct the survey. Then using face-to-face interview method, the data was collected from the underlined sample size. The approaching to the respondents, we explained the purpose of the study and assured them, as their response will be kept confidential. Then following this, we could able to obtain a consent and willingness to participate in the survey. In addition, the study also assures that there is no used material without source citation or crediting, or no improper paraphrasing of materials.

To obtain a preliminary guess about the WTP distribution, we conducted a pilot study to determine initial bid values. Pre-test surveys were conducted in March 2019 from10 respondents selected randomly from each Kebelles in a city outside sample Kebelles (01and 13), that makes 20 respondents in total. The responses of WTP from Kebele 01 were 9, 11, 14, 15, 17, 18, 21, 22, 25 and 30 ETB per month. So, the average WTP of $18.20(\approx 18)$ ETB is selected as starting bid value; the response of willing to pays from Kebele 13 were $0,2,3,3,4,5,6,6,8,9$ and 15 ETB per month. So, the average WTP of $5.80(\approx 6)$ ETB is selected as starting bid value; and sum of the two areas provide that an average WTP of 12 Birr per month. In view of this, three starting bids of Birr 6, 12 and 18 were randomly allotted to 222 sampled respondents in the final survey.

\footnotetext{
${ }^{3}$ Hypothetical bias is a case where respondents either not pay or less pay when compared to the real life situation
} 


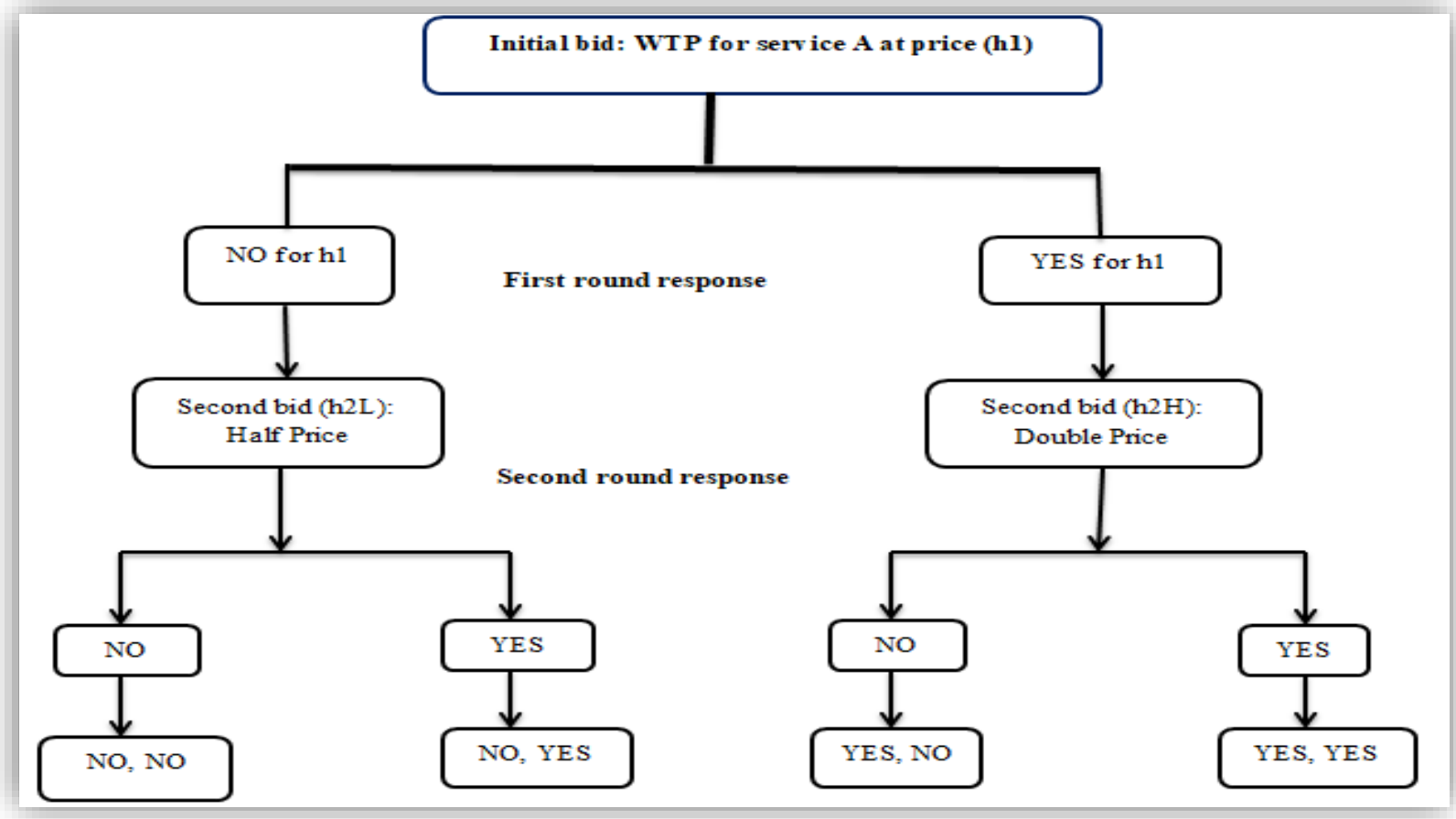

Figure 2: Set of responses for Double- Bounded Dichotomous Choice approach

\subsection{Model Specification}

\subsubsection{Empirical model}

Inquiring the respondents' WTP directly is the usual method in most CVM studies, but inquiring the payment amount, i.e. open-ended method, is not suggested. The later will often get the results of missing values for respondents find it difficult to answer [58]. This study focuses on the closed-bounded method to elicit the WTP that is to ask the respondents' WTP under a given amount. The close-bounded method can be applied and divided into single-bound, double-bound or multiple bound depends on the number of times to question. This study uses the double-bounded format by a following up questionnaire for the purpose of statistical efficiency $[54,59,60]$ and finally open ended elicitation used to find their maximum WTP for comparisons of mean from double bound. Based on its empirical evidences and theoretical superiority in efficiency gain, the study adopts the double bounded dichotomous choice format.

Let $h^{1}$ be the first bid price and $h^{2}$ be the second bid price. Then the WTP can be bounded in: $h^{1} \leq W T P<h^{2}$ the yes-no responses; $h^{1}>W T P \geq h^{2}$ for the no-yes response; $W T P \geq h^{2}$ for the yesyes response; and $W T P<h^{2}$ for the no-no response. Using econometrics model the double bounded willingness to pay data can be modeled using a logarithm function of its explanatory factors as per [61] 
$\log \left(W T P_{i, j}\right)=X_{i} \beta+\mu_{i}-------------------------------------11$

Where $W T P_{i, j}$ represents the $\mathrm{j}^{\text {'th }}$ respondents $\mathrm{WTP}$, and $\mathrm{i}=1,2$ represents the first and the second answers, $X_{i}$ is the vector of the other observable attributes of the individual which might affect one's willingness to pay, $\mu_{i}$ is error terms which follows and assumes $\mu_{i} \approx N\left(0, \delta^{2}\right)$. Depending on the arguments with related to the assumption for the average values of error terms with related to the individual covariates, it is possible to use; the bivariate probit model as proposed by [59,62], the random effects probit model Lee and Heo [62] and the interval-data logit model [54, 63]. According to Alberini [60], an estimate of bivariate probit model is preferred to that of interval data logit, when the correlation coefficient between the two consecutive bid error terms is close to zero. Therefore, after checking the correlation coefficient for the first and subsequent responses, the study used bivariate probit model ${ }^{4}$.

In using contingent valuation approach, the bid function model is described, where binary choices data from the bids are used to estimate the willingness to pay values. The second question involves the acceptance of another birr amount depending on the first answer. The study assumes the unobserved willingness to pay of the respondent $\mathrm{i} W T P_{i}^{0}$ in first question is between the lowest value $\left(W T P_{i}^{L}\right)$ and the highest value $\left(W T P_{i}^{H}\right)$. Therefore, we might have four types that result from the following up question by respondents' reply "yes "or "no". (1)YES-YES means "yes" for the bid price in first and second question, and the highest WTP in the mind of respondents will be between $\left(W T P_{i}^{H}\right)$ and infinity; (2) YES-NO presents "yes" for the first bid price but "no" for the second price, thus the highest WTP is between $W T P_{i}^{0}$ and $\left(W T P_{i}^{H}\right)$; (3) NO-YES means "no" for the first bid price but "yes" for the second price, and the highest WTP is between $\left(W T P_{i}^{L}\right)$ and $W T P_{i}^{0} ; \mathbf{( 4 )}$ NO-NO means "no" for both of the two questions and the highest WTP will be between 0 and $\left(W T P_{i}^{L}\right)$. According to [59], Lin, Fu [64] the four types can be expressed by the following equations.

$$
\begin{aligned}
& \operatorname{pr}(\text { no, } n o)=\operatorname{pr}\left(W T P_{1 i}<h^{1}, W T P_{2 i}<h^{2}\right)=\operatorname{pr}\left(x_{i} \beta_{1 i}+\varepsilon_{1 i}<h^{1}, x_{i} \beta_{2 i}+\varepsilon_{2 i}<h^{2}\right) \\
& \operatorname{pr}(\text { no, yes })=\operatorname{pr}\left(W T P_{1 i}<h^{1}, W T P_{2 i} \geq h^{2}\right)=\operatorname{pr}\left(x_{i} \beta_{1 i}+\varepsilon_{1 i}<h^{1}, x_{i} \beta_{2 i}+\varepsilon_{2 i} \geq h^{2}\right) \\
& \operatorname{pr}(\text { yes }, \text { no })=\operatorname{pr}\left(W T P_{1 i} \geq h^{1}, W T P_{2 i}<h^{2}\right)=\operatorname{pr}\left(x_{i} \beta_{1 i}+\varepsilon_{1 i} \geq h^{1}, x_{i} \beta_{2 i}+\varepsilon_{2 i}<h^{2}\right) \\
& \operatorname{pr}(\text { yes, yes })=\operatorname{pr}\left(W T P_{1 i} \geq h^{1}, W T P_{2 i} \geq h^{2}=\operatorname{pr}\left(x_{i} \beta_{1 i}+\varepsilon_{1 i} \geq h^{1}, x_{i} \beta_{2 i}+\varepsilon_{2 i} \geq h^{2}\right)\right.
\end{aligned}
$$

\footnotetext{
${ }^{4}$ To estimate bivariate probit model the mean of initial question $\mu^{1}$ and the second follow up questions $\mu 2$ are assumed independent and the covariance's are assumed zero.
} 
Where $\mathrm{h}^{1}=$ first bid price (initial bid) and $\mathrm{h}^{2}=$ second bid price (final bid or Bid2)

The parameters in equation (12), (13), (14), and (15) are estimated by Maximum log-likelihood function because of its asymptotically efficient estimator for a set of parameters [65]. Then accordingly, the log-likelihood function is sated as Eq. (16).

$$
\begin{aligned}
& \ln L=\sum_{i=1}^{n} h_{i}^{1} h_{i}^{2} \ln \left[1-\Phi\left(\frac{\log \left(W T P_{i}^{H}-X_{i} \beta\right)}{\delta}\right)\right] \\
& +h_{i}^{1}\left(1-h_{i}^{2}\right) \ln \left[\Phi\left(\frac{\log \left(W T P_{i}^{H}-X_{i} \beta\right)}{\delta}\right)-\Phi\left(\frac{\log \left(W T P_{i}^{0}\right)}{\delta}\right)\right] \\
& +h_{i}^{2}\left(1-h_{i}^{1}\right) \ln \left[\Phi\left(\frac{\log \left(W T P_{i}^{0}\right)-X_{i} \beta}{\delta}\right)-\Phi\left(\frac{\log \left(W T P_{i}^{L}\right)-X_{i} \beta}{\delta}\right)\right] \\
& +\left(1-h_{i}^{1}\right)\left(1-h_{i}^{2}\right) \ln \left[\Phi\left(\frac{\log \left(W T P_{i}^{L}\right)-X_{i} \beta}{\delta}\right)\right]------------------------16
\end{aligned}
$$

\subsubsection{Estimation of the Mean WTP}

The bivariate probit or seemingly unrelated bivariate probit model was also used to estimate the mean WTP from the double bounded dichotomous choice format. The mean willingness to pay (MWTP) from bivariate probit model (Equation 17) can be calculated using the formula specified by Haab and McConnell [57].

$$
M W T P=\frac{-\alpha}{\beta}
$$

Where $\alpha=$ coefficient for the constant term and $\beta=$ a coefficient offered bids to the respondents

The double bounded model for contingent valuation proposed by Hanemann, Loomis [54]. It allows the efficient use of the data to estimate willingness to pay (under the assumption that there is a single valuation function behind both answers and also used to estimate the mean WTP from the double bounded dichotomous choice format.

For open ended contingent valuation survey responses from maximum willingness to pay figures reported by the respondent can be simply be averaged to produce an estimate of mean WTP.

$$
\text { Mean } \mathrm{WTP}=\frac{1}{n} \sum_{i=1}^{n} y_{i}
$$


Where $\mathrm{n}$ is the numbers of household head (sample size) and " $\mathrm{y}_{\mathrm{i}}$ " is the reported maximum WTP amount by surveyed households.

\subsubsection{Variables in the model}

Households' WTP binary choice for better SWM services is the dependent variable of the model in this study. It is assumed that WTP is determined and explained by different socio economic and demographic characteristics. In the context of this study, the value that household places to get SWM services are indirectly measured by the amount they is WTP for it. The bids and socio economic and demographic variables are considered as the independent variables. The summary of variables and its description is as shown below in Table 2 .

Table 2: Description of variables

\begin{tabular}{|c|c|c|c|c|}
\hline $\begin{array}{l}\text { Categories of } \\
\text { variable }\end{array}$ & $\begin{array}{l}\text { Variable } \\
\text { name }\end{array}$ & $\begin{array}{l}\text { Number of } \\
\text { observation }\end{array}$ & Definition of the variables & $\begin{array}{l}\text { Expected } \\
\text { sign }\end{array}$ \\
\hline \multirow{2}{*}{$\begin{array}{l}\text { Joint } \\
\text { dependent } \\
\text { variable }\end{array}$} & WTP1 & 222 & $\begin{array}{l}\text { Yes or No response for the WTP questions using the first } \\
\text { initial bids }\end{array}$ & \\
\hline & WTP2 & 222 & $\begin{array}{l}\text { Yes or No response for the WTP questions using the } \\
\text { follow up bids }\end{array}$ & \\
\hline \multirow{9}{*}{$\begin{array}{l}\text { Independent } \\
\text { variables }\end{array}$} & BID PRICE & 222 & $\begin{array}{l}\text { The initial bid price (6ETB, 12ETB, and 18ETB) level } \\
\text { respondents are asked whether they can pay or not. }\end{array}$ & - \\
\hline & AGEHH & 222 & $\begin{array}{l}\text { Age of the household head (respondents) by survey time } \\
\text { in years }\end{array}$ & - \\
\hline & SEXHH & 222 & $\begin{array}{l}\text { Dummy coded } 1 \text { if the household head is male, } 0 \\
\text { otherwise }\end{array}$ & - \\
\hline & FAMSIZE & 222 & $\begin{array}{l}\text { The number of family member in that particular } \\
\text { household during survey time }\end{array}$ & - \\
\hline & $\begin{array}{l}\text { YEARS } \\
\text { EDUC }\end{array}$ & 222 & $\begin{array}{l}\text { Categorical and coded } 1=\text { If Household illiterate (Edu1), } \\
2=\text { if only read and write (Edu2), } 3=\text { if achieve Primary } \\
\text { education }(1-8 \text { grade)(Edu3), } 4=\text { if achieve Secondary } \\
\text { education ( } 9-12 \text { grade) (Edu4) and } 5=\text { if achieve } \\
\text { Certificate and above (Edu5) }\end{array}$ & + \\
\hline & MARITSTA & 222 & $\begin{array}{l}\text { Categorical and coded If } 1=\text { MARIST1(Married), } 2= \\
\text { MARIST2 (Single), } 3=\text { MARIST3(Divorced) and } 4= \\
\text { MARIST4( Widowed) }\end{array}$ & - \\
\hline & SUFDISEA & 222 & $\begin{array}{l}\text { Dummy coded 1=If a household was affected by diseases } \\
\text { because of improper SWM services, } 0=\text { Other wise }\end{array}$ & + \\
\hline & QUATWAST & 222 & $\begin{array}{l}\text { Household total Quantity of solid waste generated per } \\
\text { week in sack }\end{array}$ & + \\
\hline & MSSESAY & 222 & $\begin{array}{l}\text { Dummy and coded as } 1 \text { if a household was getting SWM } \\
\text { services as schedule, } 0=\text { otherwise }\end{array}$ & - \\
\hline
\end{tabular}




\begin{tabular}{|l|l|c|l|c|}
\hline & HOUSOWN & 222 & $\begin{array}{l}\text { Dummy and coded 1If a household has been Living in } \\
\text { their own house, 0 =otherwise }\end{array}$ & + \\
\cline { 2 - 6 } & YEARSSTAY & 222 & Number of years the respondent living in the study area & + \\
\cline { 2 - 4 } & 222 & $\begin{array}{l}\text { Aggregated household monthly income level from } \\
\text { different sources }\end{array}$ & + \\
\cline { 2 - 6 } & AWARENESS & 222 & $\begin{array}{l}\text { Categorical and coded 0 if a household is aware and has } \\
\text { perception that waste is useless, 1 somewhat useful, and, } \\
\text { 2 useful }\end{array}$ & + \\
\hline
\end{tabular}

With regard to the households' income variables, the study used the gross estimated household income. It constitutes income from different sources and which includes family members' income gain per month. Of the above variables, few variables are just explained under descriptive statistics and others are used for econometrics estimation purposes as well.

\section{Result and discussion}

\subsection{Descriptive statistics}

\subsubsection{Socioeconomic and demographic characteristics of households}

From the total 222 respondents, 2 observations were eliminated as invalid responses and the analysis of this research article was made based on the remaining 220 sample units. Out of 220 remaining sample respondents, 100(45.45\%) of the respondents are male headed and 120(54.55\%) were female headed households. From the total respondents, 192(87.27\%) households were WTP for improved SWM services and 28(12.73\%) households were not WTP for better SWM services. From non WTP respondents, 22(78.6\%) were male headed and 6(21.4\%) were female headed households (Table 4). There is statically significant relationship between sex of the household head and WTP for improved SWM service. This underline indicates that, sex is an important variable in WTP decision of households because traditionally females are more concern about their environment than males due to responsibility to general hygiene of the house.

Household head educational status has statistically significant difference between those household heads who are WTP and those are not WTP for betted SWM service supply. Therefore, household heads educational difference is important variable in WTP decision because education is always considered as a crucial factor to achieve higher degree of awareness about environmental friendly SWM services. The average schooling for the sampled household head is 5 years. Using categorical form summarizes in Table 3, 42(19.09\%) household heads have no formal education at all (illiterate), 4.09\% of respondents have attained basic education, $12.27 \%$ of respondents completed primary schooling, $28.64 \%$ 
of respondents attained secondary schooling and $35.91 \%$ of respondents have certificate and above level of education.

With regard to marital status from the total households heads, 145(65.91\%) of respondents were married while 49(22.27\%), 16(7.27\%) and 10(4.55\%) are single, divorced and widowed respectively. In addition, out of 195 willing respondents, 132(68.75\%) were married while $21.35 \%, 6.25 \%, 3.65 \%$ were single, divorced and widowed respectively. And also there is a statistically significant difference between the WTP and not WTP household heads in terms of marital status (Table 3).

In terms of access of SWM services once per week, only 153(69.55\%) household heads were getting currently SWM service and, 67(30.45\%) household heads were not get currently the SWM services. In addition to this, there is a statistically significant difference between the WTP and not WTP household heads in terms of getting current SWM services, which is significant at less than $1 \%$ level of significance (Table 3).

Having the understanding and good perception about solid wastes and its proper management is very crucial in order to manage the household solid wastes in a sustainable manner. Therefore, to know the householdse understanding or level of awareness on solid wastes and its management, selected samples were asked question about what solid waste means for them. As per the given data above, from 220 respondents $50 \%$ stated that solid waste means totally useless. In addition, $25 \%$ and $25 \%$ of the selected households responded that solid waste mean somewhat useful and useful respectively. There was a statistically significant difference between the WTP respondents AWARENESS and non-WTP respondents AWARENESS. This shows that, there is strong relationship between AWARENESS and households WTP.

Table 3: Descriptive statistics of socioeconomic and demographic characteristics of households

\begin{tabular}{|c|c|c|c|c|c|c|c|c|c|}
\hline \multirow{2}{*}{\multicolumn{2}{|c|}{ Variable }} & \multicolumn{2}{|c|}{$\begin{array}{l}\text { WTP } \\
(192)\end{array}$} & \multicolumn{2}{|c|}{$\begin{array}{l}\text { Not WTP } \\
(28)\end{array}$} & \multicolumn{2}{|c|}{$\begin{array}{c}\text { Total sample } \\
\text { (220) }\end{array}$} & \multirow[t]{2}{*}{$\chi^{2}$-test } & \multirow[t]{2}{*}{ Sig. } \\
\hline & & \multirow{2}{*}{$\frac{\text { No }}{78}$} & \multirow{2}{*}{$\begin{array}{c}\text { percent } \\
40.60\end{array}$} & \multirow{2}{*}{$\begin{array}{r}\text { No } \\
22\end{array}$} & \multirow{2}{*}{$\frac{\text { percent }}{78.6}$} & \multirow{2}{*}{$\begin{array}{l}\text { № } \\
100\end{array}$} & \multirow{2}{*}{$\begin{array}{c}\text { Percent } \\
45.45\end{array}$} & & \\
\hline SEXHH & Male & & & & & & & \multirow[b]{2}{*}{14.192} & \multirow[b]{2}{*}{$0.000 * *$} \\
\hline & Female & 114 & 59.4 & 6 & 21.4 & 120 & 54.55 & & \\
\hline \multirow{4}{*}{$\begin{array}{l}\text { MARITAL } \\
\text { STATUS }\end{array}$} & Married & 132 & 68.75 & 13 & 46.43 & 145 & 65.91 & \multirow{4}{*}{7.2744} & \multirow{4}{*}{$0.064 *$} \\
\hline & Single & 41 & 21.35 & 8 & 28.57 & 49 & 22.27 & & \\
\hline & Divorced & 12 & 6.25 & 4 & 14.29 & 16 & 7.27 & & \\
\hline & Widowed & 7 & 3.65 & 3 & 10.71 & 10 & 4.54 & & \\
\hline MSSESAV & Access SWM services & 127 & 66.15 & 26 & 92.86 & 153 & 69.55 & & \\
\hline
\end{tabular}




\begin{tabular}{|c|c|c|c|c|c|c|c|c|c|}
\hline & Not accessed & 65 & 33.85 & 2 & 7.14 & 67 & 30.45 & 8.2320 & $0.004 * * *$ \\
\hline \multirow{5}{*}{$\begin{array}{l}\text { YEARS } \\
\text { EDUC }\end{array}$} & Illiterates (Edu1) & 24 & 12.5 & 18 & 64.29 & 42 & 19.09 & \multirow{5}{*}{61.852} & \multirow{5}{*}{$0.000 * * *$} \\
\hline & Basic (Edu2) & 5 & 2.6 & 4 & 14.29 & 9 & 4.09 & & \\
\hline & Primary (Edu3) & 22 & 11.46 & 5 & 17.85 & 27 & 12.27 & & \\
\hline & Secondary (Edu4) & 62 & 32.29 & 1 & 3.57 & 63 & 28.64 & & \\
\hline & $\begin{array}{l}\text { Certificate and above } \\
\text { (Edu5) }\end{array}$ & 79 & 41.15 & 0 & 0 & 79 & 35.91 & & \\
\hline \multirow[t]{2}{*}{ HOUSOWN } & Private house & 45 & 23.44 & 6 & 21.43 & 51 & 23.18 & \multirow[t]{2}{*}{0.0554} & \multirow[t]{2}{*}{0.814} \\
\hline & Rented house & 147 & 76.56 & 22 & 78.57 & 169 & 76.82 & & \\
\hline \multirow[t]{2}{*}{ SUFDISEA } & $\begin{array}{l}\text { HHs do not affected } \\
\text { by disease }\end{array}$ & 117 & 60.94 & 23 & 82.14 & 140 & 63.64 & \multirow[t]{2}{*}{4.7485} & \multirow[t]{2}{*}{$0.029 * *$} \\
\hline & $\begin{array}{l}\text { HHs affected by } \\
\text { disease }\end{array}$ & 75 & 39.06 & 5 & 17.86 & 80 & 36.36 & & \\
\hline \multirow[t]{3}{*}{ AWARENESS } & Useless & 100 & 62.5 & 60 & 37.5 & 160 & 50 & \multirow[t]{3}{*}{1.568} & \multirow[t]{3}{*}{$0.005 * * *$} \\
\hline & Somewhat useful & 40 & 50 & 40 & 50 & 80 & 25 & & \\
\hline & Useful & 25 & 31.25 & 55 & 68.75 & 80 & 25 & & \\
\hline
\end{tabular}

Source: survey result, 2019

The survey result shows that, $80(36.36 \%)$ of the household heads were faced health problem because of improper SWM services and 140(63.64\%) were not. Out of 192 WTP respondents, 60.94\% of households were not affected by diseases and from 28 not WTP respondents $39.06 \%$ were affected by diseases. Also there is a statistically significant difference between the WTP and not WTP household heads in terms of households suffered by diseases because of improper SWM services, which is significant at less than 5\% probability level (Table 3). However, this study result was in line with a study done in Ethiopia (Jimma town) which was 83.5\% Batu and Fikadu Tolosa [66], but higher than studies done in Tanzania 63\% Mussa [13], South east Nigeria 64.4\% Oyawole, Ajayi [16], Ghana 57\% AwunyoVitor, Ishak [67], Nepal 61\% Maskey and Singh [68], Ethiopia (Addis Ababa city) 91.02\% Amiga [69] which was and Ethiopia (Injibara town) $81.06 \%$ Mulat, Worku [70]. The possible reason might be due to difference in study areas, period, design and demography.

With regard to house ownership of the respondent, $23.18 \%$ of households were live in their own houses while $76.82 \%$ live in rented houses. In addition, out of 192 WTP respondents, 45(23.44\%) of households are lived in their own house. While 147(76.56\%) of households lived in rented houses and also there is no a statistically significant difference between the WTP and not WTP household heads in terms of house ownership (Table 3). 
With regard to AGEHH variable, the mean age for WTP household heads was 38.2 years and that of non-WTP respondents was 41.5 years and there was a statistically significant difference between the mean age of WTP and non-WTP household heads (Table 4).

On the other hand, the average family size was 4.58 and the minimum and the maximum family sizes 1 and 9, for both WTP and non-WTP respondents respectively. In addition, the mean family size of WTP household heads was 4.68, and that of non-WTP was 3.928. The overall sample households mean family size was 4.58 and which is less than the national mean family size [71]. The reason was that may be household head were not interested disclosing their family size. In addition, there was no statistical significant difference between the mean family size of WTP and non-WTP household heads (Table 4).

As Table 4 indicated, the mean income of the respondents was 4451.76 ETB per month with minimum and maximum aggregate income 500ETB and 15000 ETB, respectively for both WTP and nonWTP respondents. In addition, the mean income of WTP respondents was 4695.51 ETB per month and 2780.36 ETB for non-WTP households was per month. There was a statistically significant difference between the mean monthly income of WTP and non-WTP respondents, and this shows that there is strong relationship between aggregate income of the respondent and their WTP for better SWM services supply.

Table 4: Descriptive statistics of socioeconomic and demographic characteristics of households

\begin{tabular}{|c|c|c|c|c|c|c|c|c|c|}
\hline \multirow[t]{2}{*}{ Variables } & \multicolumn{2}{|c|}{$\begin{array}{l}\text { Willingness to pay } \\
\quad(\mathrm{N}=192)\end{array}$} & \multicolumn{2}{|c|}{$\begin{array}{c}\text { Non Willingness to } \\
\text { pay }(\mathrm{N}=28)\end{array}$} & \multicolumn{3}{|c|}{$\begin{array}{l}\text { Overall } \\
(\mathrm{N}=220)\end{array}$} & \multirow[t]{2}{*}{ t-test } & \multirow[t]{2}{*}{ Sig. } \\
\hline & Mean & $\begin{array}{l}\text { Std. } \\
\text { Dev. }\end{array}$ & Mean & $\begin{array}{l}\text { Std. } \\
\text { Dev. }\end{array}$ & mean & $\max$ & $\min$ & & \\
\hline AGEHHH & 38.187 & 5.27 & 41.46 & 9.72 & 35.11 & 22 & 78 & 5.9906 & $0.000 * * *$ \\
\hline FAMSIZE & 4.677 & 2.28 & 3.928 & 2.12 & 4.58 & 1 & 9 & -1.6326 & 0.104 \\
\hline INCOME & 4695.51 & 1671.61 & 2780.36 & 1150.63 & 4451.76 & 15000 & 500 & -5.8576 & $0.000 * * *$ \\
\hline YEARSSTAY & 18.56 & 11.08 & 16.82 & 7.449 & 17.83 & 1 & 25 & -2.6505 & 0.86 \\
\hline QUATWAST & 0.99 & 0.58 & 0.455 & 0.446 & 0.92 & 0.25 & 3 & -4.6994 & $0.000 * * *$ \\
\hline
\end{tabular}

Source: Own Survey, 2019

*** statistically significant at $1 \%$ probability level

The average year of stay in the town is 17.8 years. The survey data also shows that household age and year of stay in the town are strongly related. The older the household head, the longer that she/he lives in the town. The average years of the households who are WTP and non-WTP for better SWM services have stayed in the city for 18.56 and 16.82 years respectively. Of course, it shows that there is no that much gap between the two groups of households. This finding is further strengthened by t-test, which shows the existence of insignificant relationship between the two groups of households. 
Moreover, with regard to QUATWAST variable, there is no actual measurement of solid waste generated by each household using a standard unit of measurement. Accordingly, on average each household generated 0.92 "Madaberiya", with the lowest amount 0.25 and the largest amount 3.0 'Madaberiya ${ }^{5}$ per week for both willing and non-willing households. In addition, WTP household heads generated on average 0.99 "Madabriya" solid waste per week and non-WTP household head on average 0.455 "Madaberiya" quantity of solid waste generates per week. There was a statistically significant difference between the mean weekly generated quantity of solid waste of WTP and non-WTP household heads. This shows that, there is strong relationship between QUATWAST per week and households WTP (Table 4).

\subsubsection{The dichotomous response}

The distribution of the double-bounded dichotomous choice response is in line with the law of demand theory. That means, the percentage of NO-NO response increases with the initial bid price that the respondents faced. This distribution is just what is expected. The higher the price is; the lower acceptance by the respondent. The detail is shown in Table 5 below: As Table 5 shows, the percentages of NO-NO increases as the initial bid price increase for both electricity goods. Inversely the percentages of YES-YES decreases as initial bid price increases.

Table 5: Distribution of dichotomous responses for monthly payments for better SWM services supply

\begin{tabular}{|c|c|c|c|c|c|}
\hline Initial bid & YES-YES & YES-NO & NO-YES & NO-NO & Observation \\
\hline $6 \mathrm{ETB}$ & $45(40.18 \%)$ & $39(66.10 \%)$ & $16(76.19 \%)$ & $6(21.43 \%)$ & 106 \\
\hline $12 \mathrm{ETB}$ & $45(40.18 \%)$ & $7(11.86 \%)$ & $3(14.29 \%)$ & $9(32.14 \%)$ & 64 \\
\hline $18 \mathrm{ETB}$ & $22(19.64 \%)$ & $13(22.03 \%)$ & $2(9.52 \%)$ & $13(46.43 \%)$ & 50 \\
\hline Total & $112(51.04 \%)$ & $59(26.81 \%)$ & $21(9.55 \%)$ & $28(12.73 \%)$ & 220 \\
\hline
\end{tabular}

Source: Own Survey, 2019

Table 5 indicated that, about 28(12.73\%) of the households rejected the initial offers as well as the follow up discounted bids (NO-NO). Out of the 192 WTP respondents, the percentage of households that did not accept the initial bid but accepted the second discounted bid (NO-YES) was found to be 21(9.55\%). The third category of households that accepted the initial bid but rejected the higher second follow up bid (YES-NO) were 59(26.81\%). The last category represents households who had responses for the first initial bid as well as for the higher follow up bid (YES-YES) was found to be 98(51.04\%).

\footnotetext{
${ }^{5}$ A material which looks like suck and used to store solid waste at household level
} 
This could indicates that the presence of the first response had an effects on the response of the follow up question, and which is consistent with prior studies i.e. Solomon [72] on valuation of multi-purpose tree resource using double bounded dichotomous choice elicitation format and Banga, Lokina [73] on WTP for rural water supply services using double bounded dichotomous choice elicitation format.

\subsubsection{Estimation of Mean Willingness to Pay: Comparative analysis}

Both open ended and double bounded CVM were used to compute the mean WTP. In the case of open ended format, what is the maximum amount you are WTP for better SWM services question was introduced. The open ended contingent valuation result demonstrated that the respondents' WTP of sample households ranges from 0 to 50 ETB for better SWM services. The mean and median of their WTP were 17.077ETB (\$058) and 15.25 ETB (\$0.52), respectively. This implies that the respondents' average WTP is much greater than the current SWM service charge (7ETB/month) by 10.0.77 ETB. This indicates that the current SWM service charge is not demand oriented. As a result, demand based SWM service increase the revenue stream of the municipality to improve the services supply as well as satisfaction level of urban households. Consequently, demand based SWM service should be designed and implemented in Bahir Dar city. The result of this study was less than a study done in Nepal (\$0.72) Maskey and Singh [68], Ethiopia (Injibara) which was 29.7 ETB and 11.89 ETB Mulat, Worku [66], and greater than a study done in Ethiopia (Addis Ababa and Mekelle) which is 7.07ETB and 11.89 ETB respectively Amiga [69] and Dagnew, Alemu, \& Zenebe, 2012.

Another interesting result is that the error correlation is estimated to be 0.89 justifying the use of the bivariate probit model. The success probability of WTP only in the first response (WTP1) by household head is about $86.78 \%$. Similarly, the probability of WTP only the second response (WTP2) by household head is about $57.96 \%$. The joint probability of success that household heads WTP to both responses (WTP1 and WTP2) simultaneously is not that match different from the probability of WTP only the second response (WTP2), only $57.85 \%$. As opposed to this, the joint probability that household heads fail to WTP in both of the responses is about $13.11 \%$ suggesting that they are more likely to fail to WTP both responses (WTP1 and WTP2) simultaneously (Table 6).

In addition to the open ended format, mean WTP from double bounded CV format was computed following the bivariate probit estimation. The likelihood ratio test of the model confirms the interdependence between two probit equations at less than $1 \%$ significance level. This indicated that the two equations estimated concurrently. As the model result indicated, both the initial and the follow up bid had statistically significant and negative effect on responses to the stated bids at less than $1 \%$ significance level. This implies that an increase in the amount of bids decreases the respondents' WTP. Using these 
coefficients in Table 6, from the double bounded bivariate probit estimate the mean WTP for improved SWM service was estimated using the formula by Haab and McConnell [57] (equation 18). Thus, mean of WTP estimate using Bid1 and Bid2 to be 28.74 and 40.22 ETB per month, respectively. On average for both bids mean WTP was about 34.48 ETB per month which is greater than from open ended elicitation mean WTP.

Table 6: Parameter estimates of bivariate probit model from double bounded format

\begin{tabular}{|l|l|l|l|l|l|}
\hline Payment & Variables & Coefficient & Std. Err. & $\mathrm{z}$ & $\mathrm{P}>\mathrm{z}$ \\
\hline \multirow{5}{*}{ ETB/month } & Bid1 & -.1150679 & .0200168 & -6.4 & 0.000 \\
\cline { 2 - 6 } & cons & 3.307645 & 1.138425 & 7.76 & 0.000 \\
\cline { 2 - 6 } & Bid2 & -.0307721 & .0078472 & -5.21 & 0.000 \\
\cline { 2 - 6 } & Constant & 1.238885 & .8031895 & 7.14 & 0.000 \\
\cline { 2 - 6 } & /athrho & 1.464315 & .3489631 & 5.2 & 0.000 \\
\cline { 2 - 6 } & Joint probability of success & & & & 0.5785 \\
\cline { 2 - 6 } & Joint probability of failure & & & & 34.1311 \\
\cline { 2 - 6 } & Mean WTP & & & & $31.3186^{* * *}$ \\
\cline { 2 - 6 } & Likelihood-ratio test of rho $=0$ & & & & \\
\end{tabular}

Source: survey result, 2019

\subsubsection{Estimated Total Willingness to Pay}

One of the main steps in analyzing data obtained from CVM is estimating and aggregating benefit. In line with this we estimated the total WTP and total revenue from our survey results. The result of the open ended questions was categorized into class marks following the steps to convert ungrouped frequency distribution in data to grouped frequency distribution. The class mark of each class limit was calculated following statistical procedures. Next to this, the TWTP of households for improved SWM service was estimated based on the proportion (willing versus not willing households).

The survey covered 222 households out of 63171 households in the Gondar city. The results of the study show that $192(87.27 \%)$ of the households are willing to participate for improved SWM services but not the rest sample households. As a result, the total households of sample stratification were estimated based on this ratio. It means that $55129(63171 * 0.8727=55129)$ households are WTP for improved SWM service. Expected total WTP can be calculated using cross sectional data. These 
calculations are shown in the following tables including demand curve ${ }^{6}$. For example, Haji and Tesfaye [75] estimated the total WTP of farm households for the restoration of Lake Haremaya. The author followed similar steps to estimate the total WTP, but she incorporated the whole observation for estimation. The incorporation of both willing and not willing respondents overestimates the total WTP. On the other hand, this study considered willing sample households only to estimate the total WTP. Similarly, Endalew and Tassie [76], estimated the total WTP based on the proportion of willing households.

Following the above explanations, the total number of willing households in each solid waste generated stratification was obtained by multiplying the ratio of sample households in each strata by the total number of households of the sample strata (Column 4 and 5).

Table 7: Estimated total WTP from open ended and double bounded format

\begin{tabular}{|c|c|c|c|c|c|c|c|}
\hline \multirow{2}{*}{$\begin{array}{l}\text { Stratifications based } \\
\text { on amount of solid } \\
\text { waste generate }\end{array}$} & \multirow[t]{2}{*}{$\begin{array}{l}\text { Total } \\
\text { households }\end{array}$} & \multirow[t]{2}{*}{$\begin{array}{l}\text { Sample } \\
\text { households }\end{array}$} & \multicolumn{2}{|c|}{$\begin{array}{r}\text { Willing } \\
\text { households }\end{array}$} & \multirow{2}{*}{$\begin{array}{c}\text { Total } \\
\text { Households } \\
\text { WTP for } \\
\text { better SWM }\end{array}$} & \multirow{2}{*}{$\begin{array}{l}\text { Open } \\
\text { ended } \\
\text { Total } \\
\text { WTP }\end{array}$} & \multirow{2}{*}{$\begin{array}{c}\text { Double } \\
\text { bounded } \\
\text { Total WTP }\end{array}$} \\
\hline & & & №. & $\%$ & & & \\
\hline $\begin{array}{l}\text { Low solid waste } \\
\text { generated Kebelles }\end{array}$ & 9959 & 35 & 23 & 11.98 & 6604 & 112767 & 227706 \\
\hline $\begin{array}{l}\text { Medium solid waste } \\
\text { generated Kebelles }\end{array}$ & 18280 & 66 & 51 & 26.56 & 14642 & 250021 & 504856 \\
\hline $\begin{array}{l}\text { High solid waste } \\
\text { generated Kebelles }\end{array}$ & 34932 & 121 & 118 & 61.46 & 33883 & 578573 & 1168286 \\
\hline Total & 63171 & 222 & 192 & 100 & 55129 & 941361 & $1,900,848$ \\
\hline
\end{tabular}

Source: survey result, 2019

The main objective of this section is to compare the total amount of WTP obtained from open ended and double bounded CV method. Then, the total WTP of the total households in the sample strata was calculated by multiplying the total number of willing households by the mean WTP (column 6 vs 7, and 6 vs 9). Finally, the grand total WTP was obtained by adding the WTP of the total households in each stratum. In terms of cash payment, total WTP is equal to 941361 and 1900848 ETB for open ended and double bounded format, respectively (Table7). This indicated that double bounded CV format provides better result as compared to single bounded and open ended CV formats.

\footnotetext{
6 "Demand" - The desire and ability to acquire a good or service, or the quantity of a good or service those economic agents are willing to buy at a given price 74. Alhassan, M. and J. Mohammed, Households' Demand for Better Solid Waste Disposal Services: Case Study of Four Communities in the New Juaben Municipality, Ghana. Journal of Sustainable Development, 2013. 6(11): p. 16.
} 
The total amount households are WTP to improve SWM is used as a measure of the value of the cost of poor SWM to the city. Thus, how much households are WTP is the economic cost of services improvement in the city. To arrive at this, the mean WTP from the sample is extrapolated across the population. Using the population mean permits us to extrapolate the estimates for the entire population. Therefore, the estimated aggregate WTP for Gondar city is shown in table 8 in the estimation used the following two steps: To get the estimated number of households in each WTP interval, multiply the percent of households in each interval by the total number of households in the city (Column 5 of Table 8) got 55129 WTP households in the study area. Assuming the midpoint of each WTP interval as the mean WTP (column two) multiply the number of households by this mean WTP to estimate TWTP (column six of table 8). From the total households in the study area about 7012 of them non-WTP for better SWM service provision by the city municipality.

Table 8: TWTP for improved SWM

\begin{tabular}{|c|c|c|c|c|c|}
\hline $\begin{array}{c}\text { Class Boundary } \\
\text { for WTP Amount }\end{array}$ & $\begin{array}{c}\text { Midpoint } \\
\text { WTP }\end{array}$ & \multicolumn{2}{|c|}{$\begin{array}{c}\text { Sample } \\
\text { Distribution. }\end{array}$} & $\begin{array}{c}\text { Total No } \\
\text { HHs WTP }\end{array}$ & $\begin{array}{c}\text { Total WTP for improved } \\
\text { SWM services }\end{array}$ \\
\hline$(1)$ & $(2)$ & $(3)$ & $(4)$ & $(5)$ & $(6)$ \\
\hline 0 & 0 & 28 & 12.72 & 7012 & 0 \\
\hline $3-23$ & 13 & 134 & 60.91 & 33579 & 436527 \\
\hline $24-44$ & 34 & 56 & 25.46 & 14036 & 477224 \\
\hline $45-65$ & 55 & 2 & 0.91 & 502 & 27610 \\
\hline & Total & 220 & 100 & 55129 & 941361 \\
\hline
\end{tabular}

Source: Own Survey, 2019

Total number of households (Col. (5)) is obtained by taking the proportion of sample households falling in that boundary and multiplying it by the total number of households WTP (55129). The TWTP (Col (6)), multiply midpoint WTP (Col (2)) by the total willing households Col. (5)). The grand total willingness to pay (941361 ETB) is obtained by summing up total WTP amounts at each class mark, and this is the amount all households in Gondar city are expected to pay per month if the proposed plan of improved SWM is to be applied and annually (ETB $941361 * 12=11,296,332$ ETB).

\subsection{Econometrics Analysis}

Among ten explanatory variables were used in the first and second response regression three variables (HHSEX, HOUSOWN, YEARSSTAY, QUATWAST, SUFDISEA and AWARENESS) were statistically insignificant. This means that as far as the empirical estimation conducted in this study is concerned, these variables didn't determine households' amount of offered price (bids) for improved SWM services in Gondar city and also the significant variables discussed as follow (Table 9). 
Table 9: Bivariate Probit Regression Results

\begin{tabular}{|c|c|c|c|c|c|c|}
\hline \multirow[t]{2}{*}{ Variables } & \multicolumn{2}{|c|}{ WTP1 } & \multicolumn{2}{|c|}{ WTP2 } & \multicolumn{2}{|c|}{ Marginal Effects } \\
\hline & Coefficient & $\begin{array}{l}\text { Robust } \\
\text { Std. Err. }\end{array}$ & Coefficient & $\begin{array}{l}\text { Robust } \\
\text { Std. Err. }\end{array}$ & $\mathrm{dy} / \mathrm{dx}$ & Std. Err \\
\hline SEXHH & .0260028 & .2423054 & -.1158389 & .2011117 & -.044143 & .07773 \\
\hline AGEHH & -.0594441 & $.0250914 * *$ & -.0321493 & $.017792 *$ & -.0127924 & $.0069^{*}$ \\
\hline FAMSIZE & -.0029078 & .0473474 & -.0803232 & $.0435173^{*}$ & -.0309049 & $.01689 *$ \\
\hline HHINCOME & .0002807 & $.0000769 * * *$ & .0001608 & $.00006 * * *$ & .0000639 & $.00002 * * *$ \\
\hline YEARSTAY & -.0129774 & .0102686 & -.0033584 & .0085065 & -.0013854 & .00331 \\
\hline HOUSOWN & .035197 & .2789525 & -.2719922 & .2346471 & .0759723 & .07083 \\
\hline QUATWAST & -.3710493 & .2274784 & .204591 & .1810608 & -.1058421 & .09257 \\
\hline \multicolumn{7}{|l|}{ EDUCATION } \\
\hline Edu2 & .136439 & .7153446 & .6278198 & .7200116 & .2102262 & .21237 \\
\hline Edu3 & 1.087469 & $.5444364 *$ & .7526099 & .4207261 & .2629157 & .12088 \\
\hline Edu4 & .6820753 & $.3849332 * *$ & .2639303 & .3171968 & .1045534 & .11992 \\
\hline Edu5 & .9332492 & $.3776774 * *$ & .2706551 & $.3209027 *$ & .110587 & $12146 * *$ \\
\hline \multicolumn{7}{|l|}{ MARITSTA } \\
\hline Marist2 & -.5782566 & $.3241989 *$ & .1334582 & .2417869 & .0322873 & .09115 \\
\hline Marist3 & .5790922 & .5297406 & -.1488404 & .422337 & -.0573551 & .16804 \\
\hline Marist4 & .5020623 & .7143342 & .1435234 & .4770099 & .0563113 & .1799 \\
\hline SUFDISEA & 0.02845 & 0.02485 & 0.00752 & 0.01563 & 0.0015 & 0.004 \\
\hline AWARENESS & 0.1433 & 0.1501 & -0.0879 & 0.379 & -.022143 & .06673 \\
\hline Bid1 & -.1150679 & $.0200168 * *$ & - & & -.0008347 & .00134 \\
\hline _Cons & 3.307645 & $1.1384 * * *$ & 1.238885 & .8031895 & & \\
\hline Bid2 & - & - & -.0307721 & $.0078472 * * *$ & -.0118317 & $.00317 * * * *$ \\
\hline \multicolumn{7}{|c|}{ Goodness of fit measures } \\
\hline \multicolumn{3}{|c|}{$\begin{array}{l}\rho=0.89 \\
\text { Log pseudo likelihood }=-178.40854 \\
\text { Numbers of observation }=192\end{array}$} & \multicolumn{2}{|c|}{$\begin{array}{l}\mathrm{Y}=\operatorname{Pr}\left(\mathrm{WTP}_{1}=1, \mathrm{WTP}\right. \\
\text { Prob }>\text { chi } 2=0.0000 \\
\text { Wald chi } 2(30)=106.27\end{array}$} & $=1)($ predict $)=$ & \\
\hline \multicolumn{3}{|c|}{ Wald test of rho $=0: \quad \operatorname{chi} 2(1)=17.608$} & \multicolumn{2}{|c|}{ Prob > chi2 } & & \\
\hline
\end{tabular}

Note: $* * *, * *$ and $*$ significant at $1 \%, 5 \%$ and $10 \%$ probability levels, respectively

Source: Own Survey, 2019

Age of the respondent (AGEHH) - The coefficient of Age is a negative sign, as expected, and is significant at $5 \%$ and $10 \%$ probability level in the first and second responses. The result was indicating that young people are more amount of offered price WTP for improved SWM services than elder one. 
This may be due to the fact that the older people are less informed about environmental topics than the Youngers. This may also show that younger people are more concerned with the beauty of their city. The marginal-effect results also shown that an increase in age of respondent by one year will decrease the probability of WTP the given amount of offered price in both the first and the second responses by $1.28 \%$, holding other variables are constant (Table 9). Thus negative sign result is confirms the findings of Lunojo [77]; Adenike and Titus [78]; Adebo and Ajewole [43], who also found sex to be an important in determining households WTP amount for improved solid waste management services.

Family Size of the Household (FAMSIZE) - The estimated coefficient for the family size of the household does not show clear effect on amount of offered price WTP in the first response but, it is negative and significant at $10 \%$ of probability level for the second equation (Table 10). Moreover, the marginal effect clearly shows that family size of the household has negative and significant effect on amount of offered price WTP for improved SWM services provision. The marginal effect result indicates that as one person increase in the total family size, decrease the probability of household's WTP amount of a given offered price (bid value) by $3.09 \%$, holding other variables are constant. That is the reason the big family size will be WTP relatively less amount due to the associated high running costs (i.e. budgetary constraints) (Table 9). This is similar to studies done in different parts of the world such as Ethiopia (Dagnew, Alemu, \& Zenebe, 2012; Mulat et al., 2019); Nigeria [16], Nepal [68], and Ghana [67].Tis might be due to the fact that a respondent with more family size may has a greater demand for SWM and more WTP.

Total Household Income (HHINCOME) - The estimated total household income has positive sign as expected and it is statically significant at $1 \%$ probability level in the first and second responses respectively. This shows that, demand for improved SWM services moves in the direction with changes in income. Thus, income is a strong determinant variable in explaining WTP and thus, any attempt to introduce user charges for provision of the service should take into account ability of the users in addition to their WTP. The marginal effect result also indicates that those households with higher income are WTP more for an improved SWM services than those who has lower income. If the income of the household increases by $1 \%$, the probability of being WTP the offered price will increase by $0.0064 \%$, keeping all other factors constant. This finding is in conformity with the general demand theory that income is positively related with demand for normal goods (Table 9). This result concede with findings of Yusuf, Ojo [79]; Ezebilo [80]; Rahji and Oloruntoba [81] also showed a positive correlation between income and respondents willingness to pay. Theoretically they explained that the participation of people for SWM in higher income areas is high while the participation in lower income areas is low. This shows the correlation of income with participation for SWM services. This result is also in line with the theory and 
other research results. According Kassa and Teshome [82] showed that contractors with higher paid up capital i.e., having high income returns showed a higher WTP for SWM services. This shows a positive relationship between income and WTP for improved SWM services.

Education Status of the household head (YEARSEDUC): From the five categories of educational status of the sample households, the illiterate group is taken as a control group (bases category). The remaining four educational dummies show positive sign as expected. The religious based (basic) education dummy is positive sign but not significant in the first and second responses, indicate that it is not major determinants factor WTP in the analysis. Whereas, primary education status (1-8) household heads have significant effects at $10 \%$ probability level in the first responses, secondary education (9-12) significant at 5\% probability level in the first responses and also certificate and above education status of household heads have positive effect and significant at 5\% and 10\% probability level in the first and second responses, respectively. This shows that, higher levels of education status lead to higher WTP a given amount of offered price. The marginal effect results shown, as compared to the base category (illiterate) and keeping the influence of other variables constant, being certificate and above education status of the household head would increase by $11.06 \%$ of the probability of WTP the given amounts of bid values for improved SWM services provision (Table 9). This finding that persons who have been educated at higher levels are WTP higher values for SWM services improvement confirms the findings of other works done Amiga [69]; Yusuf, Ojo [79]; Anjum [42]; Rahji and Oloruntoba [81]. The possible explanation may be due to the fact that educated people can understand easily the consequences of mismanagement of waste.

Marital Status of Respondent (MARITSTA) - From the four categories of marital status, the married group is taken as a base category. Among the remaining three marital status dummy variables only marista2 (single) household head is insignificant in the first response but, in the second response it is negative sign as expected and statically significant at $10 \%$ probability level on the given amounts of offered price (bids) WTP for improved SWM services. The remaining two marital status dummy variables are insignificant. Thus marital status dummy variables (marista3 and marista4) are not major determinant factors that influence household's WTP for improved SWM services. The marginal-effect results also show that all marital status dummy variables were not shown clear effect on WTP compared to the base category (married) as keeping the influence of other variables constant (Table 9).

Initial Bid (Bid1) - has negative coefficient and statistically significant at 1\% probability level in the first response. That is the bid 1 coefficient indicates that, negatively correlated with the probability of acceptance amount of bid1 in the first response as expected. Means that the amount of offered price (bid1) in the first response increases, the respondents would be less WTP accepted. That is consistent with the 
law of demand. However, in the marginal effect does not clearly show the effect of bid1 in the first response on the amounts of offered price WTP for improved SWM services provision (Table 9).

Final Bid (Bid2) - has negative coefficient as expected and statistically significant at $1 \%$ probability level for the follow up question or in the second response. As the bid 2 amount increases, the respondents would be less WTP and that is consistent with the law of demand and also the marginal effect in the second response show that if the amount of offered price (bid2) to the household increases by $1 \%$, the probability of being amounts of WTP will decrease by $1.18 \%$ keeping all other factors constant (Table 9).

\section{Conclusion and policy implications}

We used contingent valuation with a Double bound format followed by open-ended follow-up questions. We administered our survey via in-person interviews. We randomly selected a sample of 222 household heads, and used threaten explanatory variables in the regression models based on the degree of theoretical importance and their impact on WTP. A bivariate probit model was used to identify the determinants of households' WTP for improved SWM system and to analyze the mean WTP of households.

This study was conducted to elicit households' WTP for improved SWM in Gondar City using double bounded CV followed by open ended question. The result indicated that 192(87.27\%) of sample respondents were WTP for improved SWM services with the mean WTP of 17.0756 ETB and 34.48 ETB for open ended and double bounded CVM elicitation formats respectively. Therefore, this result indicated that double bounded format provides better result than open ended format. Consequently, special attention should be given to double bounded format than open ended format to elicit respondents' WTP for the better SWM services. Additionally, the result implies that the respondents' average WTP is much higher than the current SWM service charge. As a result, it is better to design and implement SWM service to collect more funds and deliver better service for Gondar city dwellers.

The total monthly aggregated WTP of the city is estimated as by adding the WTP of the total households in each stratum, and is equal to 941361ETB and 1900848 ETB for open ended and double bounded format, respectively. The actual WTP of the households in Gondar City may fall between these two figures. Compared to the current sanitary fees, this WTP is much higher. The citizens are eager for improved SWM, so there is plenty of room to increase the fee and acquire sufficient funds to substantially improve and modernize SWM in Gondar City. Comparing the mean WTP to what a private solid waste collector currently charges a household for its service (ETB 7 per month) offers a starting point for municipal officials in determining a more appropriate sanitation fee. 
It also attempts to identify significant explanatory variables that are assumed to influence households' amount of WTP using bivariate probit model. The result demonstrated that monthly aggregate income, education status of household head, marital status and had statistically significant positive effect on households' WTP (which make intuitive sense). This implies that the above variables increase the probability of households' WTP for improved SWM services, while Age is negative. The other nine variables have no significant impact on the likelihood that the respondent will provide a positive WTP value. The implications of the findings are that the municipality of Gondar city should consider these significant variables to design and implement improved SWM services.

\section{Declaration}

\section{Abbreviations}

CSA: Central staticall agency; CVM: Contingent Valuation Method; MSWM: Municipal Solid Waste Management; NOAA: National Oceanic and Atmospheric Administration; SWM: Solid Waste Management; MSWM: Municipal solid waste management; WTP: Willingness to Pay

\section{Ethics approval and consent to participate}

This research was submitted to the Johns Hopkins Bloomberg School of Public Health Institutional Review Board and deemed to be "non-human subjects' research." Additional approvals were not obtained from any organization regarding to this research submission.

\section{Consent for publication}

Not applicable.

\section{Availability of data and materials}

Data and publications from this project will be open access and available via an online repository.

\section{Competing interests}

The authors declare that they have no competing interests.

\section{Funding}

Not applicable

\section{Acknowledgements}

Not applicable

\section{Authors 'contributions}

KT conceived the study and paper contributed to the data analysis, interpretation, and co-authored the initial draft and subsequent drafts of the paper. AM conducted the data analysis and contributed to data interpretation and authorship of subsequent drafts of the paper. YS contributed to the data acquisition and interpretation, and authorship of the initial draft of the paper. GA contributed to the 
data acquisition and provided review of the manuscript for intellectual content. All authors read and approved the final manuscript.

\section{$\rightarrow$ Author details}

${ }^{1}$ Bahir Dar University, College of Agriculture and Environmental Science, Department of Agricultural Economics; Email: tasiekassahun@gmail.com (corresponding author)

${ }^{2}$ Bahir Dar University, College of Agriculture and Environmental Science, Department of Agricultural Economics; Email: antenehmulugeta6@gmaul.com

${ }^{3}$ Bahir Dar University, College of Agriculture and Environmental Science, Department of rural development and agricultural extension; Email: yene40@gmail.com

${ }^{4}$ University of Gondar, College of Agriculture and Environmental Science, Department of Agricultural Economics; Email: getinetasiafaw21@gmail.com

\section{Reference}

1. UNEP, U., Developing Integrated Solid Waste Management Plan Training Manual, 2009, Volume.

2. Desta, H., H. Worku, and A. Fetene, Assessment of the contemporary municipal solid waste management in urban environment: The case of Addis Ababa, Ethiopia. J Environ Sci Technol, 2014. 7: p. 107-122.

3. Lami, A., A. Fada, and H. Sanda, Assessment of Challenges Associated with Waste Disposal in Zuru Town, Kebbi State. Asian Journal of Geographical Research, 2019: p. 1-9.

4. Aleluia, J. and P. Ferrão, Characterization of urban waste management practices in developing Asian countries: A new analytical framework based on waste characteristics and urban dimension. Waste management, 2016. 58: p. 415-429.

5. Bhada-Tata, P. and D.A. Hoornweg, What a waste?: a global review of solid waste management, 2012, The World Bank.

6. Hoornweg, D. and P. Bhada-Tata, What a waste: a global review of solid waste management. 2012.

7. Sanjeevi, V. and P. Shahabudeen, Development of performance indicators for municipal solid waste management (PIMS): A review. Waste Management \& Research, 2015. 33(12): p. 1052-1065.

8. Zhu, D., et al., Improving municipal solid waste management in India: A sourcebook for policymakers and practitioners. 2007: The World Bank.

9. Omran, A. and A.O. Gebril, Municipal solid waste management practices in the central part of Libya, in The Impact of Climate Change on Our Life. 2018, Springer. p. 149-165.

10. Fenta, B.A., Waste management in the case of Bahir Dar City near Lake Tana shore in Northwestern Ethiopia: A review. African Journal of Environmental Science and Technology, 2017. 11(8): p. 393412.

11. Akhtar, S., et al., Households willingness to pay for improved solid waste management. 2017.

12. Damtew, Y.T. and B.N. Desta, Micro and small enterprises in solid waste management: Experience of selected cities and towns in Ethiopia: A review. Pollution, 2015. 1(4): p. 461-427.

13. Mussa, J., Residents' willingness to pay for improved solid waste management in Dodoma municipality, Tanzania, 2015, Sokoine University of Agriculture.

14. Mohee, R. and T. Simelane, Future directions of municipal solid waste management in Africa. 2015: Africa Institute of South Africa.

15. Mombo, F. and D. Bigirwa, The role of Sub-Saharan Africa Countries' households waste charges on sustainable cities development. 2017.

16. Oyawole, F., et al., Willingness to pay for improved solid waste management services in an urbanizing area in South-East Nigeria. Ethiopian Journal of Environmental Studies and Management, 2016. 9(6): p. 793-803.

17. Mohammed, A. and E. Elias, Domestic solid waste management and its environmental impacts in Addis Ababa city. Journal of Environment and Waste management, 2017. 4(1): p. 194-203. 
18. Gebreeyessus, G., D. Berihun, and B. Terfassa, Characterization of solid wastes in higher education institutions: the case of Kotebe Metropolitan University, Addis Ababa, Ethiopia. International journal of environmental science and technology, 2019. 16(7): p. 3117-3124.

19. Gebreslassie, M.G., et al., Assessment of the Generation Rate and Composition of Municipal Solid Waste in Mekelle City. Branna Journal of Engineering and Technology, 2019. 1(2): p. 185-197.

20. Woretaw, E., D. Woubishet, and W. Asmare, Households' preferences and willingness to pay for improved solid waste management interventions using choice Experiment approach: Debre Tabor Town, Northwest Ethiopia. Journal of Economics and Sustainable Development, 2017. 8(7): p. 16-32.

21. Endalew, B., K. Tassie, and Z. Ayalew, Non-Market Measurement Techniques of Willingness to Pay, the Case of Environmental Resources: A Review. Journal of Agriculture and Environmental Sciences, 2019. 3(2).

22. Atinkut, H.B., et al., Farmers willingness-to-pay for eco-friendly agricultural waste management in Ethiopia: A contingent valuation. Journal of Cleaner Production, 2020: p. 121211.

23. Bhattarai, K., Households' willingness to pay for improved solid waste management in Banepa municipality, Nepal. Environment and Natural Resources Journal, 2015. 13(2): p. 14-25.

24. Abate, B. and G. Goshu, Waste management in lake tana basin-Case of rapidly urbanizing Bahir Dar City, in Social and ecological system dynamics. 2017, Springer. p. 581-593.

25. Chinasho, A., Review on community based municipal solid waste management and its implication for climate change mitigation. , , . American journal of scientific and industrial research, , 2015. 6((3)): p. pp.41-46.

26. Alam, P.a.A., K., Impact of solid waste on health and the environment. . International Journal of Sustainable Development and Green Economics (IJSDGE),, 2013. 2((1)): p. pp.165-168.

27. Bogale, A. and B. Urgessa, Households' willingness to pay for improved rural water service provision: application of contingent valuation method in Eastern Ethiopia. Journal of Human Ecology, 2012. 38(2): p. 145-154.

28. Mezgebo, G.K. and Z. Ewnetu, Households willingness to pay for improved water services in urban areas: A case study from Nebelet town, Ethiopia. Journal of Development and Agricultural Economics, 2015. 7(1): p. 12-19.

29. Belay, G., M. Ketema, and M. Hasen, Households' willingness to pay for soil conservation on communal lands: application of the contingent valuation method in north eastern Ethiopia. Journal of Environmental Planning and Management, 2020: p. 1-19.

30. Gedefaw, M., Assessing the current status of solid waste management of Gondar town, Ethiopia. 2015.

31. Gizaw, Z., et al., Assessment of occupational injury and associated factors among municipal solid waste management workers in Gondar town and Bahir Dar City, Northwest Ethiopia, 2012. Journal of Medicine and Medical Sciences, 2014. 5(9): p. 181-192.

32. Mekuria, T., J. Muralitharan, and Y. Ali, GIS and Remote Sensing Based Suitable Site Selection for Solid Waste Disposal: A Case Study of Gondar Town, North West Ethiopia. 2019.

33. Mustafa, U., I. Ahmad, and M. ul Haq, Capturing willingness to pay and its determinants for improved solid waste management, 2014, Pakistan Institute of Development Economics.

34. Haq, M., U. Mustafa, and I. Ahmad, Household's willingness to pay for safe drinking water: a case study of Abbottabad district. The Pakistan Development Review, 2007: p. 1137-1153.

35. Flores, N.E., Conceptual framework for nonmarket valuation, in A primer on nonmarket valuation. 2017, Springer. p. 27-54.

36. Han, F., et al., Estimating willingness to pay for environment conservation: a contingent valuation study of Kanas Nature Reserve, Xinjiang, China. Environmental monitoring and assessment, 2011. 180(1): p. 451-459.

37. Kalbali, E., et al., Factors affecting the willingness to pay of Ghorogh forest park visitors in Iran. International Journal of Plant, Animal and Environmental Sciences, 2014. 4(3): p. 368-373.

38. Cho, S.-H., D.H. Newman, and J.M. Bowker, Measuring rural homeowners' willingness to pay for land conservation easements. Forest Policy and Economics, 2005. 7(5): p. 757-770. 
39. Ojok, J., et al., Households' Perception, Attitudes and Expectations on Solid Waste Management in Kampala, Uganda. The Journal of Solid Waste Technology and Management, 2014. 40(4): p. 335348.

40. BASIRU, H.A., ECONOMIC VALUE AND DETERMINANTS OF EFFECTIVE HOUSEHOLD SOLID WASTE COLLECTION SERVICES IN KANO, NIGERIA. 2017.

41. Ezebilo, E.E. and E.D. Animasaun, Economic valuation of private sector waste management services. Journal of Sustainable Development, 2011. 4(4): p. 38.

42. Anjum, R., Willingness to pay for solid waste management services: A case study of Islamabad. Pakistan Institute of Development Economics: Islamabad, Pakistan, 2013.

43. Adebo, G. and O. Ajewole, Gender and the urban environment: Analysis of willingness to pay for waste management disposal in Ekiti-State, Nigeria. American International Journal of Contemporary Research, 2012. 2(5): p. 228-236.

44. Khattak, N.U.R., J. Khan, and I. Ahmad, An analysis of willingness to pay for better solid waste management services in urban areas of district Peshawar. 2009.

45. Murad, M.W., M.A. Raquib, and C. Siwar, Willingness of the poor to pay for improved access to solid waste collection and disposal services. The Journal of Environment \& Development, 2007. 16(1): p. 84-101.

46. Das, S. and K. Gogoi, Community Participation for Urban Solid Waste Management: A Study on Tinsukia Municipality of Assam. 2014.

47. Sharma, H., et al., Municipal Solid Waste Management and community awareness and involvement in management practices: an overview and a case study from Gondar town of Ethiopia. International Journal of Environment and Waste Management, 2011. 7(3-4): p. 294-304.

48. Delaney, L. and F. O'Toole, Willingness to pay: individual or household? Journal of Cultural Economics, 2006. 30(4): p. 305-309.

49. Jianjun, J., et al., Measuring the willingness to pay for drinking water quality improvements: results of a contingent valuation survey in Songzi, China. Journal of water and health, 2016. 14(3): p. 504-512.

50. Omair, A., Sample size estimation and sampling techniques for selecting a representative sample. Journal of health specialties, 2014. 2(4): p. 142.

51. Seid, Y.M., Innovations in Data Dissemination at the Central Statistical Agency of Ethiopia. IASSIST Quarterly, 2010. 33(3): p. 26-26.

52. Report, G.c.S., Annual planned and executed activities report on solid waste management practice in Gondar city, Ethiopia. s. (2019)

53. Kwak, S.-Y., S.-H. Yoo, and C.-S. Kim, Measuring the willingness to pay for tap water quality improvements: results of a contingent valuation survey in Pusan. Water, 2013. 5(4): p. 1638-1652.

54. Hanemann, M., J. Loomis, and B. Kanninen, Statistical efficiency of double-bounded dichotomous choice contingent valuation. American journal of agricultural economics, 1991. 73(4): p. 1255-1263.

55. Haab, T.C., Estimation using contingent valuation data from a "dichotomous choice with follow-up" questionnaire: a comment. Journal of environmental economics and management, 1998. 35(2): p. 190194.

56. Cameron, T.A. and J. Quiggin, Estimation using contingent valuation data from a "Dichotomous choice with follow-up" questionnaire: reply. Journal of Environmental Economics and Management, 1998. 35(2): p. 195-199.

57. Haab, T.C. and K.E. McConnell, Valuing environmental and natural resources: the econometrics of non-market valuation. 2002: Edward Elgar Publishing.

58. Adamowicz, W.L., V. Bhardwaj, and B. Macnab, Experiments on the difference between willingness to pay and willingness to accept. Land Economics, 1993. 69(4).

59. Entele, B.R., Analysis of households' willingness to pay for a renewable source of electricity service connection: evidence from a double-bounded dichotomous choice survey in rural Ethiopia. Heliyon, 2020. 6(2): p. e03332.

60. Alberini, A., Efficiency vs bias of willingness-to-pay estimates: bivariate and interval-data models. Journal of environmental economics and management, 1995. 29(2): p. 169-180.

61. Fu, T.T., J.T. Liu, and J.K. Hammitt, Consumer willingness to pay for low-pesticide fresh produce in Taiwan. Journal of Agricultural Economics, 1999. 50(2): p. 220-233. 
62. Lee, C.-Y. and H. Heo, Estimating willingness to pay for renewable energy in South Korea using the contingent valuation method. Energy Policy, 2016. 94: p. 150-156.

63. Cameron, T.A. and J. Quiggin, Estimation using contingent valuation data from a" dichotomous choice with follow-up" questionnaire. Journal of environmental economics and management, 1994. 27(3): p. 218-234.

64. Lin, Y.-M., et al., Assessing the economic value of public service broadcasting in Taiwan using the contingent valuation approach. Journal of Media Economics, 2013. 26(4): p. 186-202.

65. Greene, W.H. and D.A. Hensher, A latent class model for discrete choice analysis: contrasts with mixed logit. Transportation Research Part B: Methodological, 2003. 37(8): p. 681-698.

66. Batu, M.M. and E. Fikadu Tolosa, Determinants of households' willingness to pay for improved solid waste management in Ethiopia: the case study of Jimma Town. J Environ Earth Sci, 2016. 6(22243216): p. 75.

67. Awunyo-Vitor, D., S. Ishak, and J.G. Seidu, Urban Households' willingness to pay for improved solid waste disposal services in Kumasi Metropolis. Ghana. Urban Stud Res., 2013.

68. Maskey, B. and M. Singh, Households' willingness to pay for improved waste collection service in Gorkha municipality of Nepal. Environments, 2017. 4(4): p. 77.

69. Amiga, A., Households' Willingness to Pay for Improved Solid Waste Management: The Case of Addis Abab, 2002, Addis Ababa University.

70. Mulat, S., W. Worku, and A. Minyihun, Willingness to pay for improved solid waste management and associated factors among households in Injibara town, Northwest Ethiopia. BMC research notes, 2019. 12(1): p. 401.

71. Gashaw, T., A. Bantider, and A. Mahari, Population dynamics and land use/land cover changes in Dera District, Ethiopia. Glob. J. Biol. Agric. Health Sci, 2014. 3: p. 137-140.

72. Solomon, J., Contingent Valuation of Multi-purpose Tree Resources: The Case of Arsi Zone, Ethiopia, 2004, MSc Thesis. School of Graduate Studies of Addis Ababa University, Addis Ababa.

73. Banga, M., R.B. Lokina, and A.F. Mkenda, Households' willingness to pay for improved solid waste collection services in Kampala city, Uganda. The Journal of Environment \& Development, 2011. 20(4): p. 428-448.

74. Alhassan, M. and J. Mohammed, Households' Demand for Better Solid Waste Disposal Services: Case Study of Four Communities in the New Juaben Municipality, Ghana. Journal of Sustainable Development, 2013. 6(11): p. 16.

75. Haji, J. and S. Tesfaye, Determinants of Farm Households Willingness to Pay for Restoration of Lake Haramaya Eastern Ethiopia, 2014, Haramaya University.

76. Endalew, B. and K. Tassie, Urban households' demand for improved solid waste management service in Bahir Dar city: A contingent valuation study. Cogent Environmental Science, 2018. 4(1): p. 1426160.

77. Lunojo, E., Household willingness to pay for improved solid waste management services in Njombe town council, Tanzania, 2016, Mzumbe University.

78. Adenike, A.A. and O.B. Titus, Determinants of willingness to pay for improved water supply in Osogbo Metropolis; Osun State, Nigeria. Research Journal of Social Sciences, 2009. 4: p. 1-6.

79. Yusuf, S., O. Ojo, and K. Salimonu, Households' willingness to pay for improved solid waste management in Ibadan North local government area of Oyo state, Nigeria. Journal of Environmental Extension, 2007. 6(1): p. 57-63.

80. Ezebilo, E., Willingness to pay for improved residential waste management in a developing country. International Journal of Environmental Science and Technology, 2013. 10(3): p. 413-422.

81. Rahji, M. and E.O. Oloruntoba, Determinants of households' willingness-to-pay for private solid waste management services in Ibadan, Nigeria. Waste management \& research, 2009. 27(10): p. 961965.

82. Kassa, B.A. and Y.M. Teshome, Smallholder Farmer's Willingness to Pay for Improved Soil and Water Conservation Practice: A Contingent Valuation Study in Abaro-Toga Watershed Ethiopia. American Journal of Business, Economics and Management, 2016. 3(6): p. 432. 

Figures

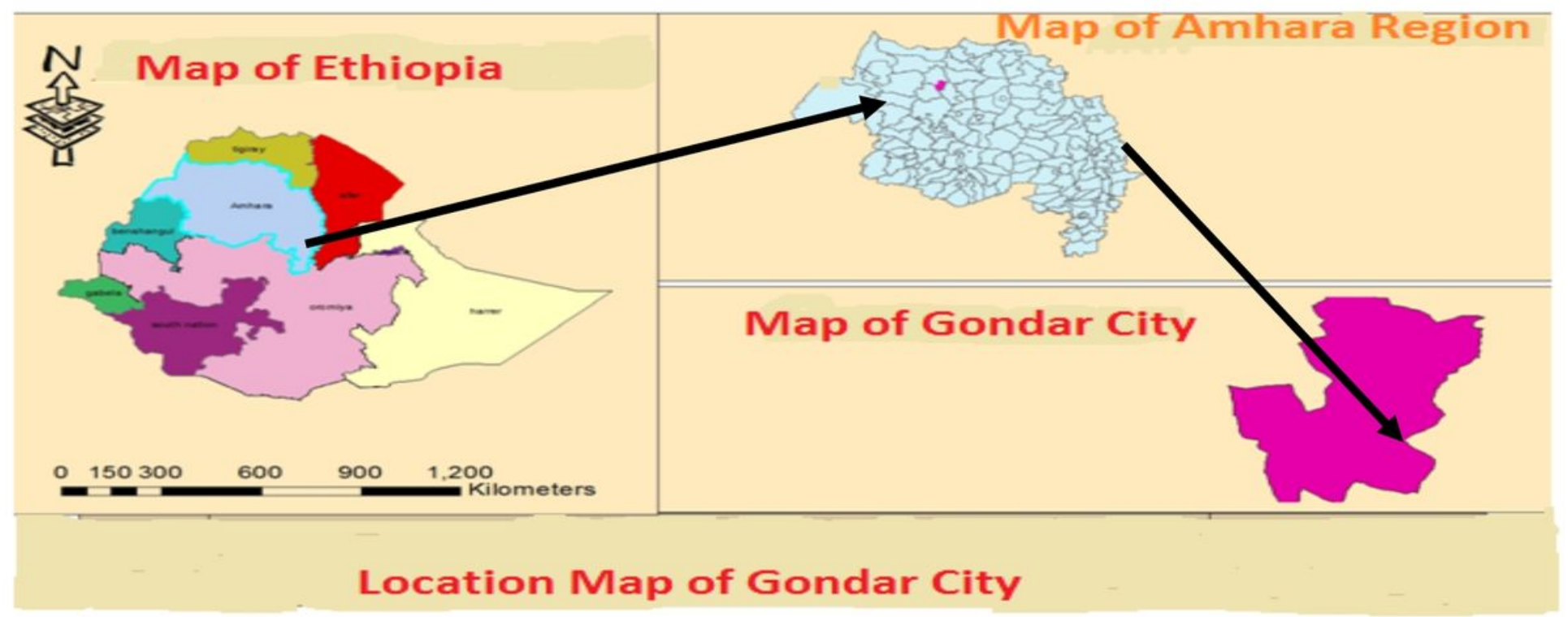

\section{Figure 1}

Location of the study area Note: The designations employed and the presentation of the material on this map do not imply the expression of any opinion whatsoever on the part of Research Square concerning the legal status of any country, territory, city or area or of its authorities, or concerning the delimitation of its frontiers or boundaries. This map has been provided by the authors. 


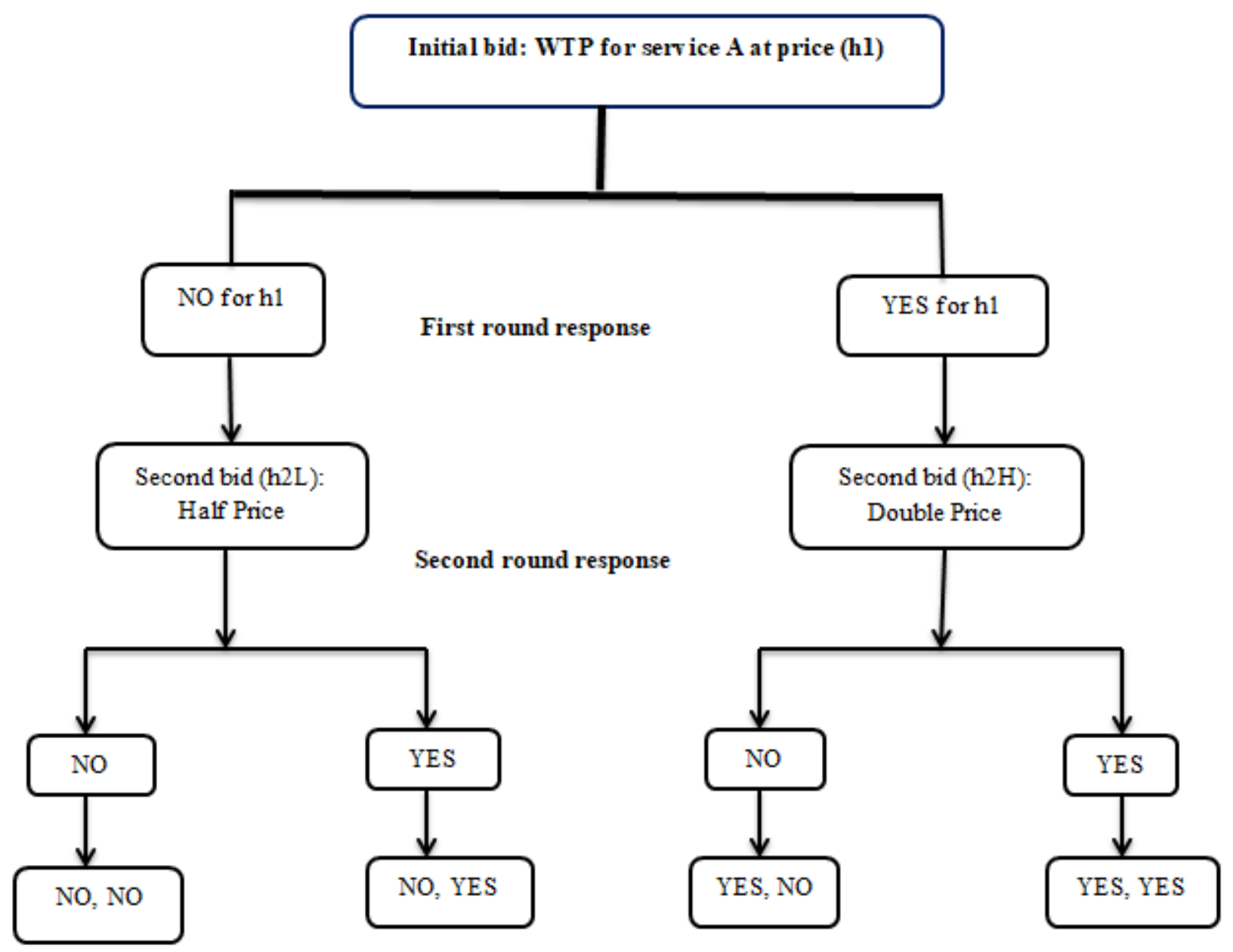

Figure 2

Set of responses for Double- Bounded Dichotomous Choice approach 